\title{
LEGISLAÇÃO AMBIENTAL E TURISMO ECOLÓGICO
}

\author{
Nicéia Rodrigues de Alencastro \\ Professor Rafael Sanzio Araújo dos Anjos
}

Monografia apresentada ao Centro de Excelênica em Turismo da Universidade de Brasília como requisito parcial para a obtenção do certificado de Especliasta em Turismo e Hospitalidade

Brasília/DF, fevereiro de 2004 


$$
\begin{gathered}
\text { UNIVERSIDADE DE BRASÍLIA } \\
\text { Centro de Excelência em Turismo } \\
\text { Curso de Especialização de Turismo e Hospitalidade }
\end{gathered}
$$

LEGISLAÇÃO AMBIENTAL E TURISMO ECOLÓGICO

Nicéia Rodrigues de Alencastro

\author{
Banca Examinadora \\ Professor Rafael Sanzio Araújo dos Anjos \\ Orientador
}

Membro da Banca

Brasília, DF, 26 de fevereiro de 2004 
Alencastro, Nicéia Rodrigues de

Legislação Ambiental e Turismo Ecológico / Nicéia Rodrigues de Alencastro. - Brasília; Universidade de Brasília, 2004

1. Turismo. 2. Turismo Ecológico. Legislação Ambiental 


\title{
NICÉIA RODRIGUES DE ALENCASTRO
}

\section{LEGISLAÇÃO AMBIENTAL E TURISMO ECOLÓGICO}

\author{
COMISSÃO AVALIADORA \\ RAFAEL SANZIO ARAÚJO DOS ANJOS \\ Professor Orientador
}

PROFESSOR

PROFESSOR

Brasília/DF, 26 de fevereiro de 2004 
UNIVERSIDADE DE BRASÍLIA

Centro de Excelência em Turismo

Curso de Especialização para Professores e Pesquisadores em

Turismo e Hospitalidade

Aos meus filhos

Alexandre, Amílcar e Débora

que cresceram incentivando meu crescimento. 


\section{UNIVERSIDADE DE BRASÍLIA \\ Centro de Excelência em Turismo \\ Curso de Especialização para Professores e Pesquisadores em \\ Turismo e Hospitalidade}

Agradecimentos

À Professora Tereza Negrão, mais que coordenadora, uma grande amiga.

Ao Professor Rafael Sanzio Araújo dos Anjos, pelo entusiasmo com que conduziu a nossa Turma.

Aos meus amigos e amigas da Turma $B$, pelo carinho e apoio que nunca faltaram. 
“...Cada pedaço desta terra é sagrado para meu povo.

Cada ramo brilhante de um pinheiro, cada punhado de areia das praias. A penumbra na floresta densa, cada clareira e inseto a zumbir são sagrados na memória e na experiência de meu povo...

Somos parte da terra e ela parte de nós. As flores perfumadas são nossas irmãs; o cervo, o cavalo, a grande águia são nossos irmãos. Os picos rochosos, os sulcos úmidos das campinas, o calor do corpo do potro, e o homem - todos pertencem à mesma família ... Os rios são nossos irmãos, saciam nossa sede. Os rios carregam nossas canoas e alimentam nossas crianças...Que será do homem se não houver mais lugar onde se possa ouvir o desabrochar de folhas na primavera ou o bater de asas de um inseto? E o que resta da vida se o homem não puder mais ouvir o choro solitário de uma ave ou o debate dos sapos ao redor de uma lagoa à noite? ...Isto sabemos: a terra não pertence ao homem; o homem pertence à terra... O que ocorrer com a terra recairá sobre os filhos da terra... O homem não tramou o tecido da vida; ele é simplesmente um de seus fios. Tudo que fizer ao tecido, fará a si mesmo..."

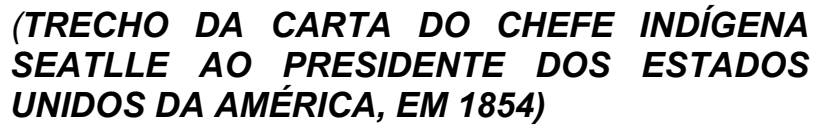


Resumo

Trata-se de estudo bibliográfico comparativo sobre Legislação Ambiental e sua aplicabilidade em Turismo Ecológico.

Legislação. Turismo. Ecologia. 
SUMÁRIO

Capítulo 1 - Apresentação - 11

Capítulo 2 - Patrimônio Ambiental - Um bem mundial - 12

2.1 - Preocupação das antigas civilizações - 12

2.2 - Brasil do descobrimento - 14

2.2.1 - Da carta de Pero Vaz - 14

2.2.2. - Das cartas de Frei Vicente - 15

2.3 - Brasil - Primórdios da a legislação ambiental - 20

2.3.1- A proteção ambiental no Brasil Colônia - 20

2.3.2 - $O$ despertar da legislação ambiental no Brasil - 21

2.3.3 - Proteção Florestal - 22

2.3.4 - A Ecologia e as Constituições Brasileiras - 23

2.3.5 - A preocupação com a Ecologia - 24

Capítulo 3 - Turismo ao longo da História - 26

3.1 - Os primeiros deslocamentos do homem - 26

3.2 - Turismo com fins lucrativos - 27

3.3 - As Guerras Mundiais e a influência no Turismo - 28

3.4 - Código Mundial de Ética do Turismo - 29

3.5 - Legislação do Turismo - 35

3.5.1 - Áreas especiais e locais de interesse turístico - 37

3.5.2 - Turismo e a Constituição de 1988 - 38

3.6 - Turismo Ecológico e os impactos sobre o meio ambiente - 40

Capítulo 4 - Relação entre a Legislação Ambiental e Legislação e Normas para o Turismo Ecológico - 42

Capítulo 5 - Conclusões - 45

Referências bibliográficas - 46 
Anexo I - Lei no 9.605, de 12 de fevereiro de 1998 Dispõe sobre as sanções penais e administrativas derivadas de condutas e atividades lesivas ao meio ambiente, e dá outras providências - 47 a 65

Anexo II - Decreto $n^{\circ} 4.653$, de 27 de março de 2003

Aprova a Estrutura Regimental e o Quadro Demonstrativo dos Cargos em Comissão e das Funções Gratificadas do Ministério do Turismo, e dá outras providências - 66 a 74 


\section{Capítulo 1 - APRESENTAÇÃO}

A preocupação com o meio ambiente surgiu da necessidade de controlar toda a espécie de poluição que nas áreas metropolitanas vem apresentando contornos cada vez mais complexos. As grandes cidades agem como pólos de atração, constituindo-se em terminais de problemas gerados nas áreas rurais e também nas urbanas de pequeno porte. A falta de planos e diretrizes leva à ocupação desordenada desses grandes centros, em razão, principalmente, dos altos índices de crescimento demográfico, nem sempre previsíveis.

Outro fator, muito atual, é o crescimento surpreendente da área de turismo, abrangendo não só o cultural em áreas muitas vezes protegidas como Patrimônio Mundial da Humanidade, que pode ser de natureza urbana, mas principalmente o turismo da natureza, no meio ambiente, conhecido como turismo ecológico ou Ecoturismo.

Partindo dessa constatação e da experiência prática de visitas a ambientes degradados pelo turismo ecológico, somando-se a isso a participação em Cursos de Direito Ambiental ou Direito do Meio Ambiente, a metodologia empregada abordou visitas ao Ministério do Turismo, Ministério do Meio Ambiente e Ministério da Educação, onde foi selecionada a legislação concernente.

Em seqüência, foram catalogadas publicações sobre os temas estudados, tendo sido selecionado e recolhido razoável material.

A partir daí, partiu-se para uma pesquisa criteriosa na bibliografia selecionada. 
Também foram examinados vários documentos que traduzem o pensamento de juristas, como decisões e doutrina sobre ambas as áreas: Turismo Ecológico e Direito do Meio Ambiente, pesquisados no âmbito dos Tribunais.

Relativamente à educação ambiental, foram feitos contatos com a Coordenação de Educação Ambiental do MEC, coletando-se material sobre a inclusão do tema nos parâmetros curriculares nacionais, que ganham flexibilidade, uma vez que o assunto pode ser contextualizado e priorizado de acordo com as diferentes realidades locais e regionais.

Para tanto, tem sido produzido material didático e paradidático, procurando o Ministério da Educação oferecer mais elementos para discussão da questão ambiental nas disciplinas dos currículos do ensino fundamental e médio, com o objetivo de proporcionar informações sobre o processo evolutivo da Educação Ambiental e seu aprofundamento e difusão no Brasil.

Quanto à bibliografia examinada constatou-se que a legislação, ainda esparsa pois se trata de assuntos que vêm sendo tratados, em geral, separadamente, pelas áreas do Direito Ambiental e do Direito do Turismo, deve ser compilada, possibilitando que as duas disciplinas sejam corretamente entendidas e aplicadas de forma prática e salutar.

CAPITULO 2 - PATRIMÔNIO AMBIENTAL - Um Bem Mundial

\section{1 - Preocupação das Antigas Civilizações}


Desde os primórdios da humanidade, a exploração das riquezas naturais gerou conflitos de interesse, criando relações jurídicas que passaram a exigir dos governantes a criação de normas com o objetivo de preservar a ordem e proteger o equilíbrio social.

Assim, princípios jurídicos ambientais são encontrados nas mais antigas e diversas civilizações.

Pesquisa realizada nos leva até Hamurabi, famoso imperador da Babilônia que reinou entre 2067 a 2025 a.C., logrou celebridade como legislador, promulgou um Código de amplas proporções, representando um dos maiores monumentos jurídicos da Antigüidade, conhecido como Olho por olho, dente por dente, onde ordenava que aquele que cortasse uma árvore sem permissão e sem necessidade, deveria plantar outra, do mesmo porte e valor, sob pena de ter cortada sua mão.

Dinastias chinesas que estiveram no poder, entre 1120 a 230 AC., impunham o reflorestamento de áreas desmatadas para preservar as florestas, necessárias para manter o equilíbrio vital da população.

A célebre Lei das XII Tábuas, de 450 a.C. também determinava prevenirse a devastação das florestas, bem comum de toda a civilização.

Outros povos da Antigüidade também se destacaram com a preocupação com a proteção ambiental. Assim, no século IV a.C., na Grécia, Platão, um dos maiores pensadores do mundo antigo e que teria vivido de 427 a 347 a.C., chamava a atenção para o papel fundamental das florestas, como fonte de equilíbrio dos ciclos das águas e defensoras dos solos contra a erosão.

Também na Índia há registro de que o Imperador Asoka, por volta de 240 a.C, teria se preocupado com a proteção das florestas, dos peixes e dos animais terrestres. 
E Marcus Tullius Cícero (105 a 43 a.C), orador e político romano, que estudou Direito e Filosofia, aprofundando-se no conhecimento de leis, considerava inimigo do Estado aquele que destruísse florestas da Macedônia e por essa razão deveria ser castigado.

\section{2 - BRASIL DO DESCOBRIMENTO - Das Belezas Naturais}

\subsection{1 - Da Carta de Pero Vaz}

Pero Vaz de Caminha, escrivão da armada de Pedro Álvares Cabral, na sua viagem do descobrimento do Brasil, é o autor da famosa Carta dirigida de Porto Seguro ao Rei de Portugal, um dos três primeiros documentos acerca do Brasil, juntamente com a Carta do Mestre João e alguns relatos de autoria de outros tripulantes da mesma esquadra.

Destes, apenas o último foi divulgado no século $\mathrm{XVI}$, porém em versão italiana.

Apesar de sua grande importância, a Carta só veio a ser conhecida com a publicação pela Imprensa Régia do Rio de Janeiro da "Corografia Brasílica", em 1817, do Padre Manoel Aires do Casal, por meio de cópia existente no Arquivo da Família Real Portuguesa. Em sua longa carta, Pero Vaz de Caminha narra com minúcias, como se fora um repórter muito experiente, tudo quanto observou do descobrimento, desde os primeiros sinais de terra, a 21 de abril, até os últimos gestos de confraternização a $1^{\circ}$ de maio, último dia de permanência da frota na costa da então Terra de Santa Cruz.

Assim, o escrivão descreve os traços físicos dos indígenas e seus costumes mais evidentes e fala da natureza que o deixou maravilhado: ancoradouros, rios, florestas enormes, ilhas, montes, cachoeiras, animais diversos, pássaros deslumbrantes, plantas exóticas e também se reporta ao clima. Onde, porém, a carta assume tom mais comovente de humanidade é ao relatar os 
encontros dos descobridores com os nativos e as trocas de objetos da civilização por flechas, arcos e penas coloridas.

O que mais teria chamado sua atenção, sem dúvida, foi a natureza exuberante das novas terras descobertas.

Eis um trecho recuperado da "Carta do Descobrimento":

“...Esta Terra, Senhor, me parece que da ponta que mais vimos contra o sul, até outra ponta que vem contra o norte, de que deste porto havemos vista, será tamanha que haverá nela bem vinte ou vinte e cinco léguas por costa. Ao longo do mar traz, em algumas partes, grandes barreiras, delas vermelhas e delas brancas, e a terra por cima toda chã e muito cheia de arvoredos, de ponta a ponta é toda plaina muito chã e mui formosa.

Sobre o sertão, nos parece, do mar, muito grande porque, a estender os olhos, não se pode ver senão terra e arvoredo que nos parecia de mui longa terra.

Nela, até agora não se pode saber que haja ouro nem prata, nem nenhuma cousa de metal, nem ferro lho vimos. Mas a terra em si, é de mui bons ares, frios e temperados como os de Entre D'Oiro e Minho, porque neste tempo de agora, assim o achamos, como os de lá. Água são muitas e infindas.

De tal maneira é graciosa que, querendo a aproveitar, dar-se-á nela tudo, por bem das águas que tem"...

\subsection{2 - Das Cartas de Frei Vicente}

Anos depois do descobrimento, foi concluída uma obra sobre a "História do Brasil - de 1500 a 1627", cujo autor, Frei Vicente do Salvador, que teria nascido durante o governo de Mem de Sá, em 1564, filho de pai português, um 
fidalgo escudeiro que depois de naufragar nas costas do "novo mundo", resolveu não retornar à terra natal. Tendo chegado à baía de Todos os Santos, estabeleceu-se no recôncavo baiano, onde contraiu matrimônio e onde também nasceram seus filhos.

O manuscrito, em pergaminho, ainda hoje se encontra na Torre do Tombo,em Lisboa, com anotações escritas à mão, nas margens, e a ele próprio atribuídas.

Na História do Brasil, ao tempo de descobrimento, desde 1500, fomos buscar nas palavras de Frei Vicente, a descrição sobre as purezas de nossas florestas, nossos rios, cachoeiras, montanhas, árvores nativas, animais selvagens ou não, aves e peixes exóticos, enfim, a beleza exuberante que tanto tem chamado a atenção dos povos de todo mundo!...

Assim descreveu Frei Vicente:

“Há no Brasil grandíssimas matas de árvores agrestes, cedros, carvalhos, vinháticos, angelins e outras não conhecidas nem em Espanha, de madeiras fortíssimas para se poderem fazer delas navios e o que El-Rei cá os mandar, sendo que da casca de algumas se tira a estopa para se calafetar e se fazerem cordas para amarras. Mas os índios naturais da terra, as embarcações que usam são canoas de um só pau, que lavram a fogo e a ferro...

Ao longo mar, e em algumas partes muito espaço dentro dele, há grandes matas de mangues, uns direitos e delgados..., que é cousa de admirar!

Não é menos admirável outra planta que nasce dos ramos de qualquer árvore, e ali cresce e dá um fruto grande e mui doce chamado caraguatá, e entre suas folhas, que são largas e rijas, se acha em todo o verão, água frigidíssima, que é o remédio dos caminhantes, onde não há fontes.

Há muitas castas de palmeiras, de que se comem os palmitos e os frutos, que são uns cachos de cocos, e se faz deles azeite para a comida e para a candeia, e das palmas se cobrem as casas. Nem menos são as madeiras do 
Brasil formosas que fortes, porque as há de todas cores, brancas, negras, vermelhas, amarelas, roxas, rosadas e jaspeadas, porém, tirado o pau vermelho a que chamam brasil, e o amarelo chamado tataiuba, e o rosado araribá, os mais não dão tintas de suas cores. E contudo são estimados por sua formosura, como se estimam outros porque estilam de si óleo odorífero e medicinal, os quais são uma árvores mui grossas, altas e direitas, chamadas copaíbas, que, golpeadas no tempo do estio com um machado, ou furadas com uma verruma ao pé, estilam, do âmego um precioso óleo, com que se curam todas as enfermidades de humor frio, e se mitigam as dores que delas procedem e saram quaisquer chagas, de tal modo que depois restam delas sinal algum.

Outras árvores se estimam ainda que agrestes, por seus saborosos frutos, que são inumeráveis as que frutificam pelos campos e matos, e assim não poderei contar senão as principais...

...Jenipapos, de que fazem os remos para os barcos, têm um fruto redondo tão grande como laranjas, o qual, quando é verde, espremido dá um suco tão claro como a água de pote, porém quem se lava nele fica negro como carvão!

Os cajueiros dão a fruta chamada cajus, de muito sumo, e os estimam tanto que no mês que o colhem não querem outro mantimento, bebida ou regalo, porque eles lhe servem da fruta o sumo de vinho e de pão umas castanhas que vêm pegadas a essas frutas e que secas lhe guardam todo o ano para fazer massapães, e ainda dá goma, como a Arábia!

Cultivam -se palmares de cocos grandes e colhem -se muitos, principalmente à vista do mar, mas só os comem a massa e lhes bebem a água que têm dentro."

“Maracujá é outra planta que sobe pelos matos, e também a cultivam e põem em latadas nos pátios e quintais; dão fruto de quatro ou cinco sortes, uns maiores, $k$ outros menores, uns amarelos, outros roxos, todos mui cheirosos e gostosos. E o que mais se pode notar é a flor, porque, além de mui formosa e de muitas cores, é misteriosa: começa no mais alto em três folhinhas, que se 
rematam em um globo, que representa as três divinas pessoas em uma divindade ou, como outros querem, os três cravos com que Cristo foi encravado, e logo tem abaixo do globo (que é o fruto) outras cinco folhas que se rematam em uma roxa coroa, representando as cinco chagas e coroa de espinhos de Cristo Nosso Senhor !.....

..Das árvores e plantas frutíferas que se cultivam em Portugal se dão as de espinho com tanto viço e fertilidade que todo o ano há laranjas, limões, cidras no Brasil e limas doces em muita abundância. Há também romãs, marmelos, figos e uvas de parreiras que se vindimam duas vezes no ano; e na mesma parreira (se querem) têm juntamente uvas em flor, outras em agraço, outras maduras, se as podam em pedaços em tempos diversos.

Há muitas melancias e abobras de quaresma e de conserva; muitos melões todo o verão, tão bons como os bons de Abrantes e com esta vantagem: que lá, entre cento, se não acham dois bons, e cá, entre cento não se acham dois ruins!...

E além de descrever as ervas medicinais, as hortaliças e várias outras plantas, arremata:

"É o Brasil mais abastado de Mantimentos, que quantas Terras há no Mundo, porque nele se dão os mantimentos de todas as outras Terras!"

\section{Os animais e outros bichos do Brasil:}

“Criam-se no Brasil todos os animais domésticos e domáveis. Há muitos porcos monteses, alguns como javalis de Espanha, os quais andam em manadas e, se o caçador fere algum, há logo de subir-se a alguma árvore, porque, vendo eles que não podem chegar-lhe, remetem todos ao ferido e aos outros em que pegou algum sangue, com tanta fereza que não se apartam.

...Outros há que chamam capiguaras, que quer dizer comedores de erva: andam sempre na água e pelos vales e margens dos rios ... Há outros animais a que 
chamam antas, que são de feição de mulas, mas não tão grandes e tem o focinho delgado e o beiço superior comprido como tromba.

...Há cutias e pacas, que são como lebres, porém mais gordas e saborosas. Há tatus cobertos de uma concha; o tamandaçu é tão grande como um carneiro, o qual é de cor parda, tem o focinho comprido e delgado, a língua da grossura de um dedo e quase de três palmos de comprido, o rabo mui povoado de cerdas, quase tão compridas como as de cavalo"...

...Há também muita diversidade de animais nocivos que não se comem, são as onças e tigres, que matam touros e, se estão famintos, comerão um exército; mas, se estão fartos, não só não ofendem a alguém, mas nem ainda se defendem e se deixam matar facilmente. Há raposas e bugios. Outros animais há que chamam preguiça, por ser tão preguiçoso e tardo em mover os pés e as mãos, que para subir em uma árvore ou andar vinte palmos há mister meia hora."

\section{As aves e peixes}

"Há no Brasil muitas galinhas bravas pelos matos, patos de lagoa e umas aves chamadas jacus, que na feição e grandeza são quase como perus. Há águias de sertão, e emas tão grandes como as de África, umas brancas outras negras que, se voarem do chão com uma asa levantada ao alto, ao modo de vela latina, correm com o vento como caravelas... Há papagaios verdes de cinco ou seis espécies e todos falam o que Ihes ensinam. As araras têm mais formosas penas. Há muitas mui grandes baleias, que no meio do inverno vem a parir nas baías e rios fundos desta costa. Há outro peixe chamado espadarte, por uma espada que tem no focinho, de seis ou sete palmos de comprido e um de largo... Há uns peixes pequenos em toda a costa. Mariscos há em muita quantidade, que se criam nos mangues, nas pedras, ou no lodo; nas restingas de areia há outras que dizem, se as tirassem do fundo, de mergulho achariam pérolas grossas.há briguigões, amêijoas, mexilhões, búzios com caracóis... Há muitas castas de". caranguejos, não só na água do mar, como dos rios e nas praias dos mangues. 
Camarões há muitos, como em Portugal, mas nos rios e lagoas de água doce, e nos recifes de águas vivas e muito polvos e lagostas."

\section{Sobre outras plantas}

“Outra planta há chamada caraguatá, de feição de erva babosa, mas cada folha tem uma braça de comprido, as quais, se deitadas de molho e pisadas, se desfazem em linho, de que se fazem linhas e cordas. Há arvores de sabão, porque com a casca das frutas se ensaboa a roupa e as frutas são tão redondas e negras que parecem de pau ébano torneado. Há muitas fontes e rios, conforme a isto se digna é de todos os louvores a terra do Brasil!"

E sobre o que há no mar e na terra do Brasil:

"É de todos os louvores a terra do Brasil, pois, primeiramente pode sustentar-se com seus portos fechados sem socorro de outras terras.

“Senão pergunto eu: de Portugal Ihe vem farinha de trigo? A da terra basta. Vinho? De açúcar se faz mui suave e, para quem quer o rijo, com o deixar ferver dois dias, embebeda como de uvas.. Azeite? faz-se de coco de palmeiras. Pano? Faz-se de algodão com menos trabalho do que lá o de linho e o de lã."

\subsection{3 - BRASIL - Primórdios Da Legislação Ambiental}

\subsection{1 - A Proteção Ambiental No Brasil Colônia}


A riqueza das florestas brasileiras chamava a atenção do Velho Mundo. A variedade de espécies aguçava a cobiça dos comerciantes clandestinos, causando preocupação para os colonizadores. Nosso país nasceu sob o símbolo do pau-brasil e a madeira era considerada o seu maior patrimônio. Portanto, era necessário protegê-lo. Portugal, como outros países da Europa, já vinha estabelecendo regras para proteger da devastação, seus recursos naturais.

Portanto, antes do descobrimento do Brasil, já existia uma legislação ambiental portuguesa. Eram normas evoluídas, cuja Ordenação de 1323 protegia aves e equiparava seu furto, para fins de aplicar medidas punitivas, a qualquer outra espécie de crime. Já em 1393 foi proibido o corte deliberado de árvores.

Quando a Terra de Santa Cruz foi descoberta, em Portugal vigoravam as Ordenações Afonsinas, consideradas o Primeiro Código Europeu, cuja compilação foi concluída em 1446. Esta foi a primeira legislação adotada no Brasil-Colônia. Poucos anos depois essa legislação foi substituída pelas Ordenações Manuelinas, concluídas em 1514. Durante sua vigência ocorreram fatos de importante destaque para o Brasil.

Os franceses atacavam constantemente as terras brasileiras, o que levou Portugal a criar o regime das Capitanias Hereditárias, em 1530, como forma de manter a extensão territorial da colônia e também de combater o contrabando. Instalaram-se, então, as grandes concessões das Sesmarias, disputadas por grandes fidalgos.

Porém outro acontecimento histórico importante ocorreu durante a vigência das Ordenações Manuelinas - a instituição do Governo Geral, em 1548, com o objetivo de centralizar o poder em nome da Coroa Portuguesa e com isso combater o contrabando do pau-brasil e contenção dos ataques ingleses à Amazônia e dos franceses ao Maranhão.

\subsection{2 - O Despertar Da Legislação Ambiental No Brasil}


Quando Tomé de Souza chegou ao Brasil, passou a legislar em complemento às Ordenações. Surgiram, então, cartas régias, regimentos, ordenações avulsas, alvarás e outras normas.

Em matéria de legislação ambiental, nas Ordenações Manuelinas, destacam-se entre seus títulos, o que proibia a caça de perdizes, lebres e coelhos com rede e outro título tipificava como crime o corte de árvores frutíferas. Fato importante decorrente dessas normas legais foi a noção de reparação de dano ecológico, quando se atribuía valores às árvores frutíferas abatidas. Nascia, assim, o Direito Ambiental no Brasil!

Com as Ordenações Filipinas, em 1603, foram compiladas as legislações anteriores e acrescentaram outras medidas, surgindo referências expressas a poluição das águas e também do lançamento, nos rios, de material que pudesse prejudicar os peixes e sujar as águas.

Com as Ordenações Filipinas, em 1603, foram compiladas as legislações anteriores e acrescentaram-se outras medidas, como a proibição de caça de certos animais e a de pesca com rede em determinada época do ano, bem como surgiram referências expressas à poluição das águas e também do lançamento, nos rios, de material que pudesse prejudicar os peixes e sujar as águas.

\subsection{3 - PROTEÇÃO FLORESTAL - As Primeiras Legislações}

O Regimento do Pau-Brasil, de 1605, pode ser considerado como a primeira legislação de proteção às florestas brasileiras. Além de impor limitações à exploração dessas árvores, para ocorrer o seu corte era necessária autorização real. Também a partir dessa época,e em torno de 1790, registra-se uma preocupação com a defesa da fauna, dos solos e das águas. Ao mesmo tempo 
foram criados os cargos de "Juízes Conservadores", com a função de julgar e aplicar penas severas, como multas altas, prisão e até mesmo degredo, para quem não respeitasse a conservação das matas brasileiras.

Em 1799 foi aprovado o primeiro Regimento de Corte de Madeiras, com regras rígidas para a derrubada de árvores e, em 1802, José Bonifácio recomendou que fossem baixadas as primeiras instruções sobre reflorestamento da costa brasileira. Porém um grande marco da proteção ambiental no Brasil, foi a criação do Jardim Botânico no Rio de Janeiro, em 1808, verdadeira área de preservação.

\subsection{4 - A Ecologia e as Constituições Brasileiras}

Proclamada a independência do Brasil em 1822, a primeira Constituição Brasileira foi aprovada em 1824.

Por conta da farta distribuição de terras e devido à instabilidade política, a devastação das florestas brasileiras era quase incontrolável, pois o interesse maior estava voltado à aplicação das áreas plantadas, conjugado com a ambição do recolhimento de rendas pelo Tesouro, que estimulavam os desmatamentos e o comércio da madeira, principalmente do pau-brasil.

No entanto, o primeiro Código Criminal do Brasil, de 1830, inclui penas severas para o corte ilegal de madeiras.

Importante marco desse período foi a promulgação da Lei $n^{\circ}$ 601, de 18 de setembro de 1850, considerada a primeira lei ecológica, inspirada nas idéias de José Bonifácio e que seria a nossa primeira Lei de Terras, com interessante avanço em matéria de preservação: obrigava ao despejo aquele que se apossasse de terras alheias e nelas derrubassem matos ou thes ateasse fogo, além de dois a seis meses de prisão, além de pagar multa e de reparar o dano causado. 
A primeira Constituição da República, de 1891, não continha referências à proteção ambiental. Mas nas décadas seguintes foram editadas medidas importantes na área ecológica. A primeira reserva florestal do Brasil foi criada em 1911.

A Constituição Brasileira de 1934 deu destaque a inovações, como a competência da União para legislar privativamente sobre as riquezas do solo, quedas d'água, florestas e sobre caça e pesca, além da proteção das belezas naturais.

O Código Florestal de 1934 foi bastante avançado.Nessa década também foram criados os Parques Nacionais de Itatiaia, o de Iguaçu e o da Serra dos Órgãos, além de Reservas Nacionais com proteção à flora e à fauna.

Na década de 60, porém, a Carta Magna de 1967 quase não abordou o tema meio-ambiente, fazendo breves referências sobre florestas, caça e pesca.

Nos períodos que se seguiram foram criados O Plano de Conservação de Solos pelo Decreto $\mathrm{n}^{\circ}$ 76.470, de 1975 e em 27 de abril de 1981, as Estações Ecológicas e Áreas de Proteção Ambiental, pela Lei $n^{\circ}$ 6.902. Em 1981, a Lei $n^{\circ}$ 6.938 fortaleceu instrumentos de política ambiental, estabelecendo:

-padrões de qualidade ambiental;

•avaliação do impacto ambiental;

•zoneamento ambiental;

- licenciamento ambiental;

-revisão de atividades efetivas ou

-potencialmente poluidoras.

\subsection{5 - A Preocupação Com A Ecologia}


A ecologia trata das inter-relações dos seres vivos e suas funções dentro de ambientes diversos. O estudo dessa rede intrincada de interação permitiu a construção de um corpo teórico para análise e compreensão daquilo que se convencionou chamar de teia da vida.

O processo de transferência de energia nos seres vivos não só definiu suas posições na cadeia alimentar, assegurando a interdependência, como determinou uma ordem, segundo a qual eles se organizaram estrutural e funcionalmente, definindo as implicações que existem na organização de vários níveis, população, comunidade e ecossistema.

Os princípios que nortearam esse arcabouço teórico são válidos na medida em que procuram elucidar mecanismos responsáveis pela organização, adaptação, distribuição e substituição das espécies vegetais e animais na biosfera.

O ser humano pode ser considerado como resultante de um quadro biológico, possuidor de uma natureza biológica geral, com impulsos puramente fisiológicos, constantes, que são integrantes da natureza humana. Ele é, também, resultante de um quadro social, que possui uma expressão própria e específica da natureza humana.

Como um ser vivo, o homem é um sistema aberto, natural, que para manter seu padrão de ordem necessita interagir com a natureza. Nessa interação ele estabelece sua posição ecológica ao mesmo tempo em que gera sua condição social. No estudo das comunidades humanas, tem se observado 0 posicionamento do ser humano dentro e diante das transformações ecológicas, sociais e econômicas, considerando-o como parte da biosfera, do ecossistema e da sociedade e, como tal, submetido a forças econômicas sociais e políticas.

Essas forças não mudam a posição do homem como ser biológico, mas dirigem a interação homem-ambiente, permitindo a transformação da natureza (biosfera) com o objetivo de desenvolver suas potencialidades e ampliar o ambiente humano. Nessa linha de estudo, procura-se evidenciar os mecanismos 
responsáveis pelas transformações ou aparecimento de novos modos de vida. Portanto, exige uma visão do homem dentro de um contexto mais amplo, onde deve estar presente a condição do ser biológico, integrante da natureza e a de ser social, integrante de uma sociedade.

Desse modo, suas reações deverão ser explicadas por meio de leis biológicas e de relações sociais. Enquanto ser biológico, o homem habita o universo físico e biológico e se coloca na biosfera comum dos constituintes da cadeia alimentar - ocupa um lugar, um espaço físico, habitat e níveis tróficos no processo de transferência de energia; como ser social ele atua sobre a natureza, procurando transformá-la para ser mais útil à sua existência, modificando-a com esse propósito.

As transformações desordenadas, no entanto, resultantes dessa interferência humana é que irão estabelecer os impactos ecológicos sobre a natureza.

\section{Capítulo 3 - Turismo ao Longo da História}

\section{1 - Os primeiros deslocamentos do homem}

O homem primitivo se deslocava com freqüência, sempre buscando melhores condições para sobreviver. Nesse processo migratório, porém, muitas vezes havia a permanência no local com melhores condições de subsistência, que em sendo favorável ao sustento dos migrantes, deixava de existir a intenção de retornar à origem. Conclui-se que esse nomadismo nada tinha a ver com as viagens que pudessem se associar a turismo.

A pré-história do turismo, pode-se dizer, teve início na Grécia Antiga, no século VIII A C, pois as pessoas viajavam para assistir os jogos olímpicos, a cada quatro anos e voltavam às suas casas; outros acreditam que os fenícios teriam sido os pioneiros, pois inventaram a moeda e promoviam o comércio e a expansão das viagens através do Mar Mediterrâneo e retornavam à origem depois de efetuar as trocas que lhes interessasse. 
Já os romanos tinham por hábito fazer viagens com a finalidade de lazer, comércio ou mesmo pelo prazer das descobertas. Muitas estradas foram construídas pelo Império Romano, entre o século II AC. E o século II d.C, facilitando as viagens dos cidadãos, ainda que estes fossem uma minoria de homens livres. De Roma saíam grupos para o mar, para o campo, parta as águas termais, ou mesmo para visitar templos ou participar de festividades. Há citações de que os romanos se deslocavam para centros de rejuvenescimento e tratamento do corpo, por prazer ou relaxamento. Há registros de que entre os séculos II e III havia peregrinações a Jerusalém e ao Santo Sepulcro.

\section{2 - Turismo com fins lucrativos}

A partir do século VII expandiram-se viagens para a comemoração de festas da primavera, da colheita ou a territórios desconhecidos, quando começaram a ser cobrados tributos e trocas de moedas.

Mas foi no século IX, quando foi descoberta a tumba de Santiago de Compostela, que se iniciaram as primeiras excursões pagas que se tem registro, organizadas por líderes de equipes, que se encarregavam de estipular regras de horários e de alimentação.

Entre os séculos XI e XIII destacaram-se as Cruzadas, movimentos militares-religiosos, organizadas para libertar o Santo Sepulcro da dominação turca, reaquecendo o mercado dos transportadores marítimos e dos organizadores das peregrinações.

As viagens de recreio passaram a ter grande importância no século $X V$, não só com a expansão dos viajantes, mas também com o uso da bússola. Os portugueses e espanhóis tiveram destaque, desempenhando papel fundamental nas viagens de descobertas do Novo Mundo, transoceânicas, cheias de mistério e novidades. 
Nesse período os europeus chegam às Américas. O Brasil é descoberto e revelado ao mundo pelas Cartas de Pero Vaz Caminha, descrevendo as belezas exuberantes de nossa terra.

Mais tarde, como citamos nas transcrições das Cartas de Frei Vicente a natureza virgem e bela da Terra Brasilis revelada ao Velho Continente pelas palavras embevecidas do seu admirador franciscano.

No século XVIII, os jovens aristocratas ingleses eram mandados a fazer viagens pelo mundo, em busca de cultura e recreação; ainda nesse século, aqueles que realizavam "the tour", depois chamados de turistas, passaram a freqüentar os spas, em busca de lazer e melhores condições de saúde.

Marcado por intensa transformação na sociedade, na economia e na política foi o século XIX, sendo para o turismo um período de grande expansão e aprimoramento.

Em 1835 o jurista e escritor Pierre Merimé(*) propôs a criação de normas visando a proteção, a conservação e a restauração do patrimônio francês que fosse importante para a cultura ou o turismo.

Thomas Cook, porém, pode ser considerado o autêntico precursor do turismo. Simples pregador ambulante, foi num congresso de abstêmios por ele organizado no ano de 1841, entre Loughborough e Leiscester, na Inglaterra, que percebeu os benefícios das viagens coletivas, favorecendo apreciável redução de preços dos transportes e hospedagens. O êxito obtido levou-o a realizar outras viagens, por vários locais da Europa. Depois os europeus visitaram a África e os Estados Unidos.

\section{3 - As Guerras Mundiais e a influência no Turismo}

Mas a Primeira Guerra Mundial, no século XX diminuiu o movimento turístico em todo o mundo. Países aliados faziam propaganda negativa, por exemplo contra a Alemanha, desestimulando as viagens a esse país. Porém na 
Itália, Mussolini incorporou à Carta do Trabalho, as atividades de lazer e descanso, estimulando as viagens de turismo, como direitos garantidos aos trabalhadores.

Em 1936, a França aprovou o regime de férias pagas, incrementando condições para a expansão do turismo.

Quando, porém, sobreveio a Segunda Guerra Mundial, a Europa, considerada o maior centro de turismo, também sofreu uma estagnação. Mas, a partir de 1945, com o término da Guerra, a aprovação da Carta das Nações Unidas e o advento da ONU - Organização das Nações Unidas, o turismo desempenhou um importante papel, como forma de intercâmbio cultural.

A partir daí, a atividade turística foi sempre evoluindo, as companhias aéreas estimulando as viagens com tarifas turísticas e econômicas, as agências de turismo se organizando e oferecendo pacotes promocionais, fortalecendo 0 movimento turístico no mundo inteiro. Surgiu, então, com a nova realidade mundial, a necessidade de uma nova especialidade no sistema legal: o Direito do Turismo, transcendendo os outros ramos jurídicos, pois se ocupa do Direito Civil, Direito Comercial, Direito do Consumidor, Direito Internacional, privado e público, enfim, uma legislação específica da área.

\section{4 - O surgimento do Código Mundial de Ética do Turismo}

A Organização Mundial do Turismo - OMT, principal organização internacional na área de viagens e de turismo tem a incumbência de servir como Tribunal mundial para as questões políticas relacionadas com essa atividade e representa uma fonte do mais alto conhecimento especializado em turismo no mundo. A OMT conta com 139 países e mais de 350 membros filiados, representantes das administrações locais, associações turísticas, bem como empresas do setor privado, inclusive Companhias Aéreas e redes de hotelaria. Um dos marcos para o desenvolvimento responsável e sustentável do turismo mundial foi o estabelecimento do Código Mundial de Ética do Turismo. Seu texto 
foi inspirado em inúmeros códigos profissionais que o precederam e que traduzem as mudanças significativas da sociedade mundial, ao final do século XX.

O Código Mundial de Ética do Turismo tem sido utilizado para ajudar a minimizar os efeitos negativos do turismo sobre o meio ambiente e sobre 0 patrimônio cultural. A preparação do Código foi resultante de uma resolução adotada na Assembléia Geral da OMT, em Istambul, em 1997. foi constituído um Comitê especial para prepara-lo.

A Comissão das Nações Unidas para o Desenvolvimento Sustentável, reuniu-se em Nova lorque, no início de 1999 para aprovar o Código. Foram recebidas inúmeras contribuições de organizações não-governamentais e sindicais e do setor privado, de mais de setenta Estados membros e de várias entidades. Os dez artigos que compõem o Código Mundial de Ética do Turismo foram aprovados por unanimidade durante a Assembléia Geral da OMT, realizada em Santiago do Chile, em outubro de 1999.

Considerando o rápido crescimento da atividade turística, mundialmente, com poderosos efeitos, positivos e negativos, sobre o meio ambiente e também sobre a economia , sobre os fluxos turísticos e sobre as populações autóctones, a OMT objetivou, através dos dez princípios do Código, pacificar de forma clara, os pressupostos em se baseia a atividade turística, embasando-se em diversos instrumentos legais de cunho internacional, ocorridos em vários momentos, assim enumerados:

-Convenção de Varsóvia, sobre o transporte aéreo, de 1929

-Convenção Internacional de Aviação Civil de Chicago, de 1944 e Convenções de Tóquio, Haia e Montreal, a ela relacionadas

-Declaração Universal dos Direitos Humanos, de 1948

-Convenção sobre Facilidades Alfandegárias para o Turismo, de 1954, e Protocolo associado

-Pacto Internacional dos Direitos Econômicos, Sociais e Culturais, de 1966

-Pacto Internacional dos Direitos Civis e Públicos, de 1966 
-Convenção sobre a Proteção do Patrimônio Mundial, Cultural e Natural, de 1972

-Declaração de Manila sobre o Turismo Mundial, de 1980; Resolução da $6^{\text {a }}$ Assembléia Geral da OMT, em Sofia, que adotou a Carta do Turismo e Código do Turista, em 1985

-Convenção sobre os Direitos da Criança, em1990

- Resolução da 9a Assembléia Geral da OMT, em Buenos Aires, relativa às matérias sobre facilidades para viagens e segurança dos turistas

-Declaração do Rio de Janeiro sobre Meio Ambiente e Desenvolvimento, de junho de 1992

-Resolução da $11^{a}$ Assembléia Geral da OMT, no Cairo, sobre Prevenção do Turismo Sexual de Crianças com Fins Comerciais

-Declaração de Manila sobre Efeitos Sociais do Turismo, de 1977; Convenções e Recomendações adotadas pela Organização Internacional do Trabalho (OIT), em matéria de Convenções Coletivas, de Proibição de Trabalho Forçado e do Trabalho Infantil, de Defesa dos Direitos dos Povos Autóctones, de Igualdade de Tratamento e Não-Discriminação do Trabalho.

O Código Mundial do Turismo, com seus dez princípios, aspira ser um documento vivo, pois seus signatários entendem que somente a cooperação permitirá proteger o futuro do setor turístico e aumentar a sua contribuição para a prosperidade econômica, para a Paz e para o entendimento de todas as nações. O seu grande objetivo é promover uma ordem jurídica, englobando todos os países do mundo, de forma eqüitativa e responsável. A seguir são comentados, resumidamente, os Princípios do Código Mundial de Ética do Turismo.

\section{Contribuição do turismo para compreensão e o respeito mútuo entre homens e sociedades.}

A promoção dos valores éticos comuns à humanidade e a sua compreensão, em um espírito de tolerância e de respeito pela diversidade das crenças religiosas, filosóficas e morais são fundamento e, simultaneamente, conseqüência de um turismo responsável.

As atividades turísticas devem ser conduzidas em harmonia de acordo com as tradições das regiões e dos países receptores, respeitando suas leis, usos e costumes.

Assim como as autoridades públicas têm o dever de assegurar a proteção aos turistas, estes devem evitar qualquer tipo de agressão, respeitando o meio ambiente e o patrimônio cultural do lugar visitado.

2. Turismo, instrumento de desenvolvimento individual e coletivo. 
Atividade geralmente associada ao repouso, à diversão, ao desporto, ao acesso à cultura e à natureza, o turismo deve ser concebido e realizado como meio privilegiado de desenvolvimento individual e coletivo.

É fator de auto-educação, de tolerância mútua e de aprendizagem sobre as diferenças entre os povos e suas culturas.

Todos os tipos de exploração de seres humanos, principalmente de crianças, vão contra os objetivos fundamentais do turismo. O Direito Internacional recomenda seja rigorosamente combatida qualquer manifestação de violência e desrespeito às legislações nacionais e locais.

Devem ser incentivadas as viagens por motivo de religião, saúde, educação e de intercâmbios culturais.

\section{Turismo, fator de desenvolvimento sustentável}

Este é, sem dúvida, um dos princípios fundamentais para o estudo que estamos realizando.

Todos os agentes envolvidos no desenvolvimento turístico têm o dever de salvaguardar 0 ambiente e os recursos naturais, na perspectiva de um crescimento econômico sadio, contínuo e sustentável, capaz de satisfazer eqüitativamente as necessidades e as aspirações das gerações presentes e das futuras.

Todos os tipos de desenvolvimento turístico que permitam economizar os venham a evitar a produção de dejetos, devem ser privilegiados e encorajados recursos naturais raros e preciosos, principalmente a água, e a energia e que pelas autoridades públicas nacionais, regionais e locais.

A distribuição no tempo e no espaço dos fluxos de turistas, especialmente a que resulta de férias de trabalho e das férias escolares, e buscar um melhor equilíbrio na freqüência, de forma a reduzir a pressão da atividade turística sobre o meio ambiente e aumentar o seu impacto benéfico na indústria turística e na economia local.

A infraestrutura deve ser planejada e as atividades turísticas programadas de forma a proteger o patrimônio natural, constituído pelo ecossistema e pela biodiversidade, e preservar as espécies ameaçadas da fauna e da flora selvagens.

Os agentes do desenvolvimento turístico, mais ainda os profissionais, devem permitir que Ihes sejam impostos obstáculos ou limitações a suas atividades, quando elas forem exercidas em zonas sensíveis: regiões desérticas, polares ou de altas montanhas, zonas costeiras, florestas tropicais ou zonas úmidas ou reservas protegidas

O turismo de natureza e o ecoturismo são formas de turismo especialmente enriquecedoras e valorizadas, sempre que preservem o patrimônio natural e que as populações locais respeitem e se ajustem à capacidade de carga dos locais turísticos.

\section{O turismo, fator de aproveitamento e enriquecimento do Patrimônio Cultural da Humanidade.}


Todos os recursos turísticos pertencem ao patrimônio comum da humanidade.

As atividades e as políticas de turismo deverão ser desenvolvidas respeitando o patrimônio cultural, arqueológico e artístico, que devem ser preservados também para as gerações futuras.

A preservação e a restauração dos monumentos e dos museus, assim como os santuários e locais históricos ou arqueológicos devem ser prioritárias para receber os turistas.

Os recursos financeiros obtidos com a atividade turística devem permitir a sobrevivência e o desenvolvimento da cultura e artesanato tradicionais do local visitado.

\section{5. $O$ turismo, atividade benéfica para os países e para as comunidades de destino.}

As políticas públicas devem ser orientadas a contribuir para a melhoria do nível de vida das populações dos locais visitados. As comunidades receptoras dos turistas devem participar dos benefícios econômicos e sociais e também culturais que o turismo gera, sobretudo na criação de empregos diretos e indiretos.

A arquitetura e o planejamento urbanístico, bem como as atividades de hotelaria, alojamentos e alimentação devem se integrar no contexto econômico e social dos moradores, devendo ser dada prioridade à contratação de mão de obra dos trabalhadores locais.

Nas zonas costeiras e nas ilhas, bem como nas zonas rurais ou nas áreas serranas, onde o turismo representa, muitas vezes as raras oportunidades de trabalho para a população local, deve ser dada especial atenção.

\section{As obrigações dos agentes de desenvolvimento turístico.}

Os profissionais de turismo, sempre que couber, deverão dar assistência, cooperando com as autoridades públicas, quanto à segurança, proteção sanitária e prevenção de acidentes daqueles que necessitarem de seus serviços. Também zelarão pela existência de sistemas de seguros e assistência apropriados. Devem oferecer aos turistas informações objetivas e reais sobre os destinos, as condições de viagem, de receptividade, assegurando transparência das cláusulas contratuais acertadas.

Os contratos deverão ser respeitados em tudo que for oferecido, no que se refere ao preço, à qualidade dos serviços e também no que se referir à natureza e passeios ofertados.

Quando necessário, deverão ser cumpridas as obrigações indenizatórias, no caso de não cumprimento contratual. Os órgãos públicos, as autoridades, o governo de forma geral, especialmente em casos de crises, deverão informar aos cidadãos sobre as condições difíceis e dos perigos que os turistas poderão encontrar nos seus deslocamentos ao exterior.Os profissionais do turismo também deverão contribuir para o pleno desenvolvimento cultural e espiritual dos turistas, facilitando o exercício de suas práticas religiosas durante os deslocamentos.A imprensa e demais meios de comunicação, principalmente os que se dedicam ao turismo, deverão oferecer informações reais e equilibradas 
sobre os acontecimentos e situações atuais, capazes de influenciar a freqüência turística.

\section{Direito ao Turismo}

O direito de todos ao turismo deve ser entendido como conseqüência do direito ao descanso e ao tempo livre e às férias escolares ou profissionais. A Declaração Universal dos Direitos Humanos, em seu artigo 24, garante a todos esse direito.

A possibilidade de acesso à descoberta de riquezas históricas, culturais, patrimoniais ou naturais do mundo, consiste em direito igual a todos os habitantes do Planeta.

A participação cada vez mais ampla no turismo nacional ou internacional é uma das melhores expressões de crescimento pessoal e não deve ser dificultada.

O turismo associativo, com seu caráter social, permitindo à grande parte dos cidadãos o acesso ao lazer e às viagens deverá sempre ser apoiado pelas autoridades.

Assim, o turismo dos idosos, dos jovens, dos portadores de dificuldades e das famílias em geral, deverá ser não só incentivado, mas também facilitado.

\section{Liberdade de deslocamento turístico}

A liberdade de circulação, no interior dos países ou de um Estado para outro, conforme o artigo 13 da Declaração dos Direitos Humanos, deve ser respeitada e incentivada, a fim de beneficiar os turistas e visitantes, que poderão ter acesso às zonas de trânsito e de estada, bem como aos locais turísticos e culturais, sem exageradas formalidades.

Os turistas deverão ter o acesso facilitado a todos os meios de comunicação disponíveis, podendo beneficiar-se de acesso fácil às áreas de serviços administrativos, judiciários e de saúde locais, bem como facilitado o seu acesso e contato com autoridades consulares do seu país de origem.

Os procedimentos administrativos de cruzamento de fronteiras estabelecidos pelos Estados, ou mesmo decorrentes de acordos internacionais, os vistos e formalidades alfandegárias devem ser facilitados e adaptados, de maneira a facilitar a liberdade de deslocamento turístico.

Sempre que os países de origem, em função da situação econômica, possam oferecer facilidades para que os turistas disponham de crédito de divisas conversíveis em outro país, devem facilitar essa transação.

Os turistas e visitantes serão, assim, beneficiados com os mesmos direitos dos cidadãos do país visitado, principalmente quando à confidenciabilidade de seus dados pessoais.

\section{O Direito dos Trabalhadores e dos Empresários da indústria turística.}

Os direitos fundamentais dos trabalhadores e dos empresários da área turística e atividades afins devem ser assegurados pelas administrações quer dos 
Estados de origem, quer dos países de destino, com especial atenção, considerando as limitações decorrentes da sazonalidade de suas atividades e da dimensão global de sua indústria.

Tanto os trabalhadores assalariados, como os autônomos da indústria turística ou atividades afins têm o direito e o dever de adquirir formação apropriada e atualizada. Também a esses profissionais deverá ser garantida a devida proteção social.

Toda a pessoa física ou jurídica que demonstrar qualificações e disposição necessárias ao desenvolvimento profissional na área de turismo, deverá ter reconhecido seu direito de atuar nesse âmbito.

Assim também as pequenas e médias empresas devem ter reconhecido o livre acesso ao setor turístico, com um mínimo de restrições legais.

A colaboração e as relações equilibradas entre empresas de países emissores e receptores devem ser prioritárias para 0 desenvolvimento sustentável do turismo.

\section{0 - Aplicação dos princípios do Código Mundial de Ética do Turismo.}

Os setores públicos e privados envolvidos com a área turística cooperarão com a aplicação dos presentes princípios, devendo zelar pelo controle de sua efetivação.

Os agentes do desenvolvimento turístico reconhecem o papel dos organismos internacionais, em evidência a Organização Mundial do Turismo, bem como das organizações não-governamentais, promotores em matéria de desenvolvimento turístico, na proteção dos direitos humanos, do meio ambiente e da saúde, respeitando os princípios gerais do direito internacional.

Os mesmos agentes manifestam a intenção de submeterem, para fins de conciliação, os litígios relativos à aplicação ou interpretação do Código Mundial de Ética do Turismo, a um terceiro organismo, imparcial, denominado Comitê Mundial de Ética do Turismo.

\section{5 - Legislação do Turismo}

Desde o seu descobrimento, o Brasil descrito por Pero Vaz de Caminha, escrivão da armada de Pedro Álvares Cabral, assim também, como Frei Vicente do Salvador, referidos no Capítulo 2 deste trabalho, já chamava a atenção, principalmente dos povos europeus.

Em "Sociologia do Turismo" , (2001) Maria das Graças Menezes Paiva afirma que 
"As viagens dos estrangeiros ao Brasil e a outros países da América Latina, da África e da Ásia datam dos séculos XV e XVI. O nosso país e toda a América Latina sempre foram objeto de curiosidade de 'desbravadores', que aliavam ao espírito de aventura o interesse pela natureza e a possibilidade de realizarem negócios vantajosos".

Era necessário, pois, a instituição de uma estrutura capaz de comportar a recepção dos viajantes. Alguns historiadores registram que no início do século XVII teria aparecido o primeiro hoteleiro, em São Paulo, chamado Marcos Lopes, e poucos anos mais tarde, uma cigana chamada Francisca Rodrigues, montava uma estalagem e talvez o que se chamaria um primeiro restaurante de gastronomia d São Paulo. Já no século XVIII, um visitante chamado Charles de Burton, teria feito a primeira classificação das hospedarias paulistanas.

Mas somente no século passado os governantes brasileiros passaram a se preocupar com o Turismo. Em 1938, o Decreto-lei n 406 previu autorização governamental para a venda de passagens aéreas, marítimas e rodoviárias. Em 1940, o Decreto $n^{\circ} 2.440$ tratou, exclusivamente, de empresas e agências de viagens e turismo, como estabelecimentos de assistência remunerada aos viajantes, classificando-as em categorias e determinando a todas a obrigatoriedade de registro prévio junto aos órgãos do governo, inclusive para viagens de excursão.

Mais tarde, o Decreto $n^{\circ} 44.883$, de 1958, instituiu a Comissão Brasileira de Turismo - COMBRATUR, com atribuições típicas, regimentalmente de planejamento turístico, porém extinta poucos anos depois, pelo Decreto $\mathrm{n}^{\circ} 572$, de 1962.

Posteriormente, por meio do Decreto-lei $n^{\circ}$ 55, de 18 de novembro de 1966, foi implantado o Sistema Nacional de Turismo e criado o Conselho Nacional de Turismo - CNTur, além da Empresa Brasileira de Turismo - Embratur, vinculada ao então Ministério da Indústria e do Comércio, depois Ministério da Indústria, do Comércio e do Turismo. Tinha a empresa a responsabilidade pelo trabalho de 
organização e estímulo ao turismo, estímulo esse que foi otimizado com a criação de fundos para financiamento de projetos de desenvolvimento, comoo Fundo Geral de Turismo - Fungetur, criado em 1971, bem como o Fundo de Investimento Social de Turismo - Fiset, de 1974.

Também foram assinados vários convênios com Bancos Oficiais, para facilitar a abertura de linhas de crédito destinadas ao setor.

Ainda no período anterior à Constituição Federal vigente, pela Lei $n^{\circ} 6.505$, de 1977, o legislador definiu como atividades turísticas aquelas que, sob condições especiais, explicitadas pelo Poder Executivo, fossem prestadas por agentes econômicos que trabalhassem com meios de hospedagem de turismo estabelecimentos destinados a prestar serviços dirigidos a hóspedes, em aposentos mobiliados e equipados, com alimentação e outras necessidades dos usuários, a exemplo de hotéis, albergues, pousadas e hospedarias, entre outros. Também foram incluídos os serviços prestados por "restaurantes turísticos", assim denominados os estabelecimentos destinados à prestação de serviços de alimentação e que, por sua localização ou tipicidade, pudessem ser considerados de interesse turístico. São incluídas, por fim, as Agências de Turismo, as empresas de transportes turísticos, excetuando-se as Companhias de transporte aéreo, e incluindo-se todas as empresas prestadoras de serviços turísticos, além de outras entidades com atividades regularmente reconhecidas pelo Poder Executivo como de interesse para o turismo.

\subsection{1 - Áreas especiais e locais de interesse turístico}

A Lei $n^{\circ}$ 6.513, de 1977, em seu art. $3^{\circ}$ define como áreas especiais os trechos contínuos do território nacional, inclusive suas águas territoriais, a serem preservadas e valorizadas no sentido cultural e natural, e destinados à realização de planos e projetos de desenvolvimento turístico.

Por outro lado, conforme o art. $4^{\circ}$ do mesmo dispositivo legal, os locais de interesse turístico são os trechos do território nacional, compreendidos ou não, em áreas especiais, destinados por sua adequação ao desenvolvimento de atividades turísticas e à realização de projetos específicos e que compreendam 
bens, não sujeitos a regime específico de proteção, e os respectivos entornos de proteção - espaço físico necessário para o acesso ao local de interesse turístico e à sua conservação, e entorno de ambientação - espaço físico necessário à harmonização do local turístico com a paisagem em que se situar.

As áreas e os locais, assim como os bens culturais e naturais protewgidos por legislação específica devem constar de um inventário, sempre atualizado, mantido pela Embratur, a quem compete pesquisar, estudar e levantar elementos necessários à declaração de Área Especial ou Local de Interesse Turístico. Em casos de tratar-se de espaço físico localizado em área de fronteira, compete à Embratur notificar o Ministério das Relações Exteriores, para sua intermediação, podendo sugerir a realização de gestões junto ao Governo do país limítrofe, possibilitando uma ação coordenada em relação à área situada no outro território. De acordo com essa mesma legislação, Estados e Municípios também podem, complementarmente, solicitar a instituição de suas próprias áreas especiais e locais de interesse público.

\subsection{2 - O Turismo e a Constituição de 1988}

Tratando-se o Turismo de uma realidade social e de um potencial econômico nacional, não poderia ficar à margem de uma proteção jurídica própria.

O art. 180 da Cata Máxima brasileira vigente determina:

“ A União, os estados, o Distrito Federal e os Municípios promoverão e incentivarão o turismo como fator de desenvolvimento social e econômico".

Trata-se de uma norma que pretendeu constitucionalizar essa realidade, incentivando os entes públicos a promoverem o turismo como fator de desenvolvimento social e econômico. Essa disposição revelou $0 \quad 0$ reconhecimento da importância do setor para a economia do país, assim como para o desenvolvimento da sociedade. Porém o texto constitucional não 
estabeleceu qualquer mecanismo que pudesse instrumentalizar a vontade do legislador constituinte.

A determinação de que os administradores públicos devem promover e incentivar o turismo não eram suficientes para torná-la realidade.

As atividades e os serviços turísticos, bem como a formulação, a coordenação e execução das políticas nacionais de turismo constituíam responsabilidades da Embratur, autarquia especial, criada nos termos do art. 11 do Decreto $n^{\circ} 55$, de 18 de novembro de 1966, vinculada ao antigo Ministério da Indústria do Comércio e do Turismo. Pela Lei $n^{\circ}$ 8.181, de 28 de março de 1991, esse órgão passou a denominar-se Instituto Brasileiro de Turismo, vinculado à Secretaria do Desenvolvimento Regional da Presidência da República.

Atualmente, com a criação do Ministério do Turismo e a aprovação de sua Estrutura Regimental, pelo Decreto $\mathrm{n}^{\circ}$ 4.653, de 27 de março de 2003, ficou estabelecida sua área de competência:

I - política nacional de desenvolvimento do turismo;

II - promoção e divulgação do turismo nacional, no País e no exterior;

III - estímulo às iniciativas públicas e privadas de incentivo às atividades turísticas; e

IV - planejamento e coordenação, supervisão e avaliação dos planos e programas de incentivo ao turismo.

Na estrutura Organizacional do Ministério do Turismo, além dos órgãos de assistência direta ao Ministro, encontram-se o órgão colegiado, chamado de Conselho Nacional de Turismo - CNT e a entidade vinculada EMBRATUR Instituto Brasileiro de Turismo.

O Decreto $n^{\circ}$ 4.686, de 29 de abril de 2003, dispõe sobre o Conselho Nacional de Turismo, determinado sua composição, com representação de vários Ministérios: da Cultura, da Defesa, do Desenvolvimento Agrário, do Desenvolvimento, Indústria e Comércio Exterior, da Integração Nacional, da Justiça, do Meio Ambiente, do Planejamento, Orçamento e Gestão, das Relações 
Exteriores, do Trabalho e Emprego, dos Transportes, da Fazenda, assim como um representante da Casa Civil da Presidência da República e um representante de cada indicada, quais sejam: Embratur, Banco do Brasil, Banco do Nordeste, Banco Nacional de Desenvolvimento Econômico e Social - BNDES, Caixa Econômica Federal, Banco da Amazônia, INFRAERO, Superintendência da Zona Franca de Manaus - SUFRAMA, além do principal dirigente de várias entidades mencionadas no art. $2^{\circ}$, inciso VI, do Decreto $n^{\circ} 4.686 / 2003$, já mencionado.

\section{6 - Turismo Ecológico e o Desenvolvimento Sustentável}

Desde os primórdios da filosofia e da teologia, as interações homem e natureza e, em conseqüência, homem e meio ambiente, têm sido objeto de reflexão. As grandes preocupações tem girado em torno não só de fazer-se justiça social, mas encontrar-se um ponto de equilíbrio para a crise socioeconômica e ambiental que aflige a humanidade.

As políticas públicas de um grande número de nações, acentuadamente no mundo ocidental, que o desenvolvimento sustentável tornou-se ponto de honra no ideário das últimas décadas. Em 1983, a Organização das Nações Unidas criou a Comissão Mundial sobre Meio Ambiente e Desenvolvimento, como organismo independente que, em sua primeira missão, para atender apelo da Assembléia Geral das Nações Unidas, materializou um importante documento, o relatório "Nosso Futuro Comum, responsável pelas primeiras conceituações oficiais, formais e sistematizadas sobre desenvolvimento sustentável, comceituado como idéia-mestra deste estudo.

O relatório, no capítulo "Busca do Desenvolvimento Sustentável", definiu, genericamente, como "aquele que atende às necessidades do presente sem comprometer a possibilidade de as gerações futuras atenderem a suas p'roprias necessidades.". E registra que essa modalidade de desenvolvimento sustentável vem sendo debatido e estudado intensamente. O que se procura é um conceito consensual, sintético e operacional de aceitação por todas as culturas do mundo. 
E qual seria a aplicabilidade do "desenvolvimento sustentável" dentro da área de turismo? Qual a sua relação com o turismo ecológico ou ecoturismo?

As alternativas de turismo são bastante diversificadas. Em sua obra Turismo -A Indústri do Século XXI, Oto Di Beltrão (Novo Século, 2001), discorre sobre vários tipos de turismo procurados por milhares de pessoas a cada ano, em diversos países, conforme seus fatores culturais. Assim, cita o Turismo Lúdico, para amantes de apostas (em Las Vegas, Punta Del Este, Mônaco); o Turismo Cultural, para o turista que busca conhecer as civilizações, os museus, teatros e galerias de arte ( como em Paris, Nova lorque, Roma, Veneza, Ouro Preto, Olinda,p.ex); Turismo de Compras, para quem viaja coma finalidade de percorrer grandes centro comercias da moda (Milão, Tóquio, Hong Kong, São Paulo...); Turismo Gastronômico, para quem aprecia degustar as mais variadas culinárias (além da Europa e Estados Unidos, Brasil, do Amazonas ao Rio Grande do Sul); e entre outros, chega ao Turismo Ecológico.

Diz o autor que "a prática do turismo ecológico consiste em desenvolver atividades voltadas ao esclarecimento da importância de preservar e criar alternativas econômicas sem destruir a natureza", E que "segundo os órgãos especializados do setor. O turismo ecológico é uma atividade econômica de grande retorno e que abrange um público especifico, com um alto grau de afinidade com a natureza e um poder aquisitivo elevado, assim como um grau de consciência bem mais apurado em relação aos outros adeptos dos demais segmentos turísticos.

Nem todos os autores pesquisados concordam, porém, essa conceituação, na íntegra. Em "Sustentabilidade Ecológica no Turismo", as autoras Dóris Santos de Faria e Kária Saraiva Carneiro (UnB, 2001), lembram que assim como ocorre com o conceito de sustentabilidade e de desenvolvimento sustentável, há uma indefinição a respeito do turismo ecológico e ecoturismo. E citam Selva e Coutinho (2000) que se referem à incompatibilidade entre ecoturismo e turismo ecológico, que seria a mesma entre teoria e prática, dado ao que é proposto pelo departamento de turismo (no Brasil) e o que é realizado na prática. E que, segundo esses autores, o "turismo ecológico é considerado o segmento no qual 
os turistas e promotores de viagens procuram o contato direto com os mais diferentes ambientes naturais, entretanto sem a preocupação com o equilíbrio ecológico, ou mesmo com a compreensão dos fluxos e dinâmica que são estabelecidos no ambiente. A expressão ecoturismo, por sua vez, surgiria para designar a modalidade de turismo, cujas bases estão fincadas nas propostas do desenvolvimento sustentável: comprometimento com as gerações futuras, justiça social e eficiência econômica, considerando o ambiente nas suas múltiplas conexões - naturais, econômicas, sociais e culturais."

Assim, conforme as fontes citadas, a relação do turismo com o meio ambiente dá-se, principalmente, por meio da paisagem, transformada em produto a ser consumido. Invariavelmente, são observadas modificações onde ocorre o turismo - e não somente nomeio natural, como na comunidade local.

Verifica-se que vários estudiosos do assunto referem-se de forma indiferente a ecoturismo ou turismo ecológico. No entanto, a expressão Turismo Ecológico, desenvolvido junto à natureza, em que visitantes procuram usufruir as suas belezas, evitando ou minimizando ao máximo os impactos negativos que possam the causar, deve ser o mais apropriado, porque junta-se a ele 0 comprometimento de desenvolver e transmitir uma consciência para esta e para as gerações futuras.

\section{CAPITULO 4 - Relação entre a Legislação Ambiental e Legislação e Normas para o Turismo Ecológico}

A legislação ambiental no Brasil surge com o próprio descobrimento, importada que foi de Portugal, que já vinha protegendo seus recursos naturais da depredação, inculcada, ao que parece, na raça humana. A pesquisadora Ann Helen Wainer, em sua obra "Legislação Ambiental Brasileira", (Forense, 1991) informa que essa legislação era bastante evoluída, destacando alguns dispositivos relevantes (Ordenações) como, por exemplo, a que protegia as aves 
e equiparava seu furto, para efeitos criminais, a qualquer outra espécie crime, datada de 9 de novembro de 1326; também o corte deliberado de árvores frutíferas.cuja proibição teria constado de uma norma 12 de março de 1393.

Esses dispositivos legais vindos com os colonizadores, poder-se-ia dizer, já seriam uma semente embrionária da legislação ambiental no Brasil.

Todo o estudo legislativo direcionado para a área do ambiente tem por objeto limitar o impacto das atividades humanas sobre os elementos, muitas vezes indefesos, do meio natural. Alguns estudiosos, como o Professor Toshio Mukai, entendem que o Direito Ambiental não é um ramo jurídico autônomo porque apresenta uma natureza interdisciplinar. $\mathrm{Na}$ verdade, nenhum ramo jurídico é autônomo, considerando que todos mantém relações com outros, dos quais se utilizam para resolver suas pendência.

É o que ocorre com o Direito Ambiental e o Direito do Turismo voltado para a ecologia, que se inter-relacionam, não só entre si, mas também com o Direito Civil, o Direito Penal, o Direito Administrativo, o Direito Tributário. A legislação aplicável nessas áreas vai sendo enriquecida com a jurisprudência decorrente das decisões dos Tribunais.

Um ambiente ecologicamente equilibrado, como previsto na Constituição Federal, a que o povo tem direito, é, ao mesmo tempo, responsabilidade de todos. Não se pode tratar a Natureza como uma inimiga, mas como uma aliada, de quem também dependemos. Por isso, com mais razão, aqueles que se dedicam ao Turismo Ecológico, já que não há uma legislação específica somente para essa área, têm por obrigação conhecer e divulgar as normas jurídicas aplicáveis à proteção do meio ambiente.

Assim, a Política Nacional de Turismo, instituída para cumprir o comando constitucional de promoção e incentivo ao turismo, como fator de desenvolvimento social e econômico, tendo por finalidade o seu equacionamento como fonte de renda nacional, devendo ser formulada, coordenada e executada pela EMBRATUR, conforme art. $2^{\circ}$ da Lei n 8.181, de 28 de março de 1991. 
O Decreto $n^{\circ} 448 / 92$ determina que a Política Nacional de Turismo deve ter como balizas a prática do turismo como forma de promover a valorização e a preservação do meio ambiente, patrimônio natural e cultural do país, e a valorização do homem, como o destinatário final do desenvolvimento turístico e do meio ambiente ecologicamente equilibrado.isolados tratando de uma e outra área

Assim, encontramos em dispositivos legais isolados, recomendações para que os turismólogos voltados para o turismo ecológico sejam também responsáveis por transmitir aos turistas os princípios básicos sobre preservação do meio ambiente.

O tema da proteção ao meio ambiente é da mais alta relevância, mas também de complexibilidade. Até a promulgação da Lei $n^{\circ} 9.605$, de 1998, que trata dos Crimes contra o Meio Ambiente, aplicava-se a Lei $n^{\circ}$ 6.938/81 ( Lei da Política Nacional do Meio Ambiente), complementada pelos ditame $s$ da Lei $n^{\circ}$ 7.347/85 - Lei da Ação Civil Pública.. No entanto, os degradadores da natureza eram submetidos a um sistema ultrapassado de sancionamento administrativo e penal.Geralmente o infrator era premiado, submetendo-se, quando muito, à pena de multa.

Com o advento da Lei $n^{\circ}$ 9.605, de 12 de fevereiro de 1998, que dispõe sobre as sanções penais e administrativas derivadas de condutas e atividades lesivas ao meio ambiente, o Brasil vivia sob a falência da norma. A responsabilidade criminal por atos atentatórios ao ambiente passou a ser instrumento de política criminal, para observar o cumprimento do princípio constitucional da prevenção, instituindo-se, assim, o Direito Penal Ambiental., com autonomia para estabelecer preceitos e postulados próprios que o diferenciam de outros campos do Direito Criminal.

A flexibilização das normas legais para que todos tenham direito ao meio ambiente ecologicamente equilibrado, no que pertine a condutas integrantes da dimensão da responsabilidade, é conseqüente da própria evolução da sociedade. 


\section{CAPÍTULO 5 - CONCLUSÕES}

Pelo estudo bibliográfico realizado, enfocando a legislação ambiental e as normas legais sobre turismo ecológico, constata-se que tanto os problemas de uma ou outra área, nasceram com a própria criação da humanidade. O homem sempre se utilizou da natureza, usufruindo tudo o que ela que the pode oferecer para a sua sobrevivência física ou para o se prazer. Porém nunca deixou de hostilizá-la, por maldade ou ignorância.

Porém, ainda que motivado pelos resultados econômico-financeiros, o Brasil procurou garantir a proteção do meio ambiente, com a elaboração de farta legislação. O mesmo não aconteceu com tal riqueza em relação ao turismo ecológico, muitas vezes ele próprio responsável pela destruição da identidade dos lugares, principalmente pela

Entre os aspectos negativos conseqüentes do turismo ecológico, quando irresponsável e não orientado, podem ser contabilizados: a poluição das águas, a destruição das trilhas e da vegetação, além de distúrbios à vida selvagem, prejudicando a conservação das espécies, além de descaracterizar a paisagem autóctone.Agrava-se o problema, ainda, com a população excessiva em sítios históricos e a disseminação da desordem do espaço natural, sem que haja um estudo prévio sobre as condições dos lugares explorados.

Ainda não estão suficientemente sensibilizados os nossos legisladores para coibir os abusos ocorridos, em detrimento da evolução do país. Em relação a outras áreas do turismo, consideramos ainda escassas a legislação e a literatura sobre turismo ecológico no Brasil. Pelo estudo comparativo realizado verificamos que são poucos os setores da sociedade, entre eles os órgãos públicos voltados para esse segmento, até a escolas dedicadas essencialmente aos serviços educacionais e profissionais, os envolvidos com as mudanças profundas que se devem realizar para que o turismo voltado para a natureza seja normatizado 
como uma área especial, de tal forma que os impactos positivos dele resultantes sejam imensamente superiores aos negativos.

\section{REFERÊNCIAS BIBLIOGRÁFICAS}

ANTUNES, Paulo Bessa - Direito Ambiental, Rio de Janeiro, $5^{\mathrm{a}}$ ed., Lúmen Júris, 2001

ARBACHE,Jorge Saba - O Mercado de Trabalho na atividade econômica do turismo no Brasil, Brasília, Ed. Universidade de Brasília, 2001

BADARÓ. Rui Aurélio de Jacerda - Direito do Turismo.São Paulo, Ed. SENAC, 2003

CRETELLA Júnior, José -Primeiras Linhas do Direito, Rio de Janeiro, Editora Forense, 2000

DIAS, Reinaldo - Turismo Sustentável e Meio Ambiente, São Paulo, Ed. Atlas, 2003

EMBRATUR/IBAMA - Diretrizes para uma Política Nacional de Ecoturismo - Grupo de Trabalho Interministerial , Brasília, 1994

FARIA, Dóris Santos de, e CARNEIRO, Kátia Saraiva - Sustentabilidade Ecológica no Turismo, Brasília/DF, Editora Universidade de Brasília, 2001

GLADSTON, Mamede - Direito do Turismo -: legislação específica aplicada, São Paulo, Atlas, 2001

JÚNIOR, Luiz Carlos Aceti - Direito Ambiental e Direeito Empresarial. Rio de Janeiro, América Jurídica, 2002

LIMA, Maria José Araújo. Ecologia Humana, Petrópolis/RJ, Ed. Vozes, 1984

LUTZENBERGER, José. Ecologia - Do Jardim ao Poder, Porto Alegre/RS, Ed. L\&PM, 1985

MACHADO, Paulo Affonso Leme - Direito Ambiental Brasileiro, São Paulo, Editora Revista dos Tribunais, 1982

MILARÉ, ÉDIS - Direito do Ambiente, São Paulo, Editora Revista dos Tribunais, 2001

MINISTÉRIO DA EDUCAÇÃO - A Implantação da Educação Ambiental no Brasil, Brasília/DF, 1998 


\begin{abstract}
ANEXO I
LEI No 9.605, DE 12 DE FEVEREIRO DE 1998

Dispõe sobre as sanções penais e administrativas derivadas de condutas e atividades lesivas ao meio ambiente, e dá outras providências.
\end{abstract}

O PRESIDENTE DA REPÚBLICA , faço saber que o Congresso Nacional decreta e eu sanciono a seguinte Lei:

\title{
CAPÍTULO I
}

\section{DISPOSIÇÕES GERAIS}

\section{Art $1^{\circ}(\mathrm{VETADO})$}

Art $2^{\circ}$ Quem, de qualquer forma, concorre para a prática dos crimes previstas nesta Lei, incide nas penas a estes cominadas, na medida da sua culpabilidade, bem como o diretor, o administrador, o membro de conselho e de órgão técnico, o auditor, o gerente, o preposto ou mandatário de pessoa jurídica, que, sabendo da conduta criminosa de outrem, deixar de impedir a sua prática, quando podia agir para evitá-la.

Art $3^{\circ}$ As pessoas jurídicas serão responsabilizadas administrativa, civil e penalmente conforme o disposto nesta Lei, nos casos em que a infração seja cometida por decisão de seu representante legal ou contratual, ou de seu órgão colegiado, no interesse ou benefício da sua entidade.

Parágrafo único. A responsabilidade das pessoas jurídicas não exclui a das pessoas físicas, autoras, co-autoras ou partícipes do mesmo fato.

Art $4^{\circ}$ Poderá ser desconsiderada a pessoa jurídica sempre que sua personalidade for obstáculo ao ressarcimento de prejuízos causados à qualidade do meio ambiente.

Art. $5^{\circ}($ VETADO)

\section{CAPÍTULO II}

DA APLICAÇÃO DA PENA 
Art $6^{\circ}$ Para imposição e gradação da penalidade, a autoridade competente observará:

I - a gravidade do fato, tendo em vista os motivos da infração e suas conseqüências para a saúde pública e para o meio ambiente;

II - os antecedentes do infrator quanto ao cumprimento da legislação de interesse ambiental;

III - a situação econômica do infrator, no caso de multa.

Art $7^{\circ}$ As penas restritivas de direitos são autônomas e substituem as privativas de liberdade quando:

I - tratar-se de crime culposo ou for aplicada a pena privativa de liberdade inferior a quatro anos;

II - a culpabilidade, os antecedentes, a conduta social e a personalidade do condenado, bem como os motivos e as circunstâncias do crime indicarem que a substituição seja suficiente para efeitos de reprovação e prevenção do crime.

Parágrafo único. As penas restritivas de direitos a que se refere este artigo terão a mesma duração da pena privativa de liberdade substituída.

Art. $8^{\circ}$ As penas restritivas de direito são:

I - prestação de serviços à comunidade;

II - interdição temporária de direitos;

III - suspensão parcial ou total de atividades;

IV - prestação pecuniária;

V - recolhimento domiciliar.

Art $9^{\circ}$ A prestação de serviços à comunidade consiste na atribuição ao condenado de tarefas gratuitas junto a parques e jardins públicos e unidades de conservação, e, no caso de dano da coisa particular, pública ou tombada, na restauração desta, se possível.

Art 10. As penas de interdição temporária de direito são a proibição de o condenado contratar com o Poder Público, de receber incentivos fiscais quaisquer outros benefícios, bem como de participar de licitações, pelo prazo de cinco anos, no caso de crimes dolosos, e de três anos, no de crimes culposos.

Art 11. A suspensão de atividades será aplicada quando estas não estiverem obedecendo às prescrições legais. 
Art 12. A prestação pecuniária consiste no pagamento em dinheiro à vítima ou à entidade pública ou privada com fim social, de importância, fixada pelo juiz, não inferior a um salário mínimo nem superior a trezentos e sessenta salários mínimos. O valor pago será deduzido do montante de eventual reparação civil a que for condenado o infrator.

Art 13. O recolhimento domiciliar baseia-se na autodisciplina e senso de responsabilidade do condenado, que deverá, sem vigilância, trabalhar, freqüentar curso ou exercer atividade autorizada, permanecendo recolhido nos dias e horários de folga em residência ou em qualquer local destinado a sua moradia habitual, conforme estabelecido na sentença condenatória.

Art. 14. São circunstâncias que atenuam a pena:

I - baixo grau de instrução ou escolaridade do agente;

II - arrependimento do infrator, manifestado pela espontânea reparação do dano, ou imitação significativa da degradação ambiental causada;

III - comunicação prévia pelo agente do perigo iminente de degradação ambiental;

IV - colaboração com os agentes encarregados da vigilância e do controle ambiental.

Art 15. São circunstâncias que agravam a pena, quando não constituem ou qualificam o crime:

I - reincidência nos crimes de natureza ambiental;

II - ter o agente cometido a infração:

a) para obter vantagem pecuniária;

b) coagindo outrem para a execução material da infração;

c) afetando ou expondo a perigo, de maneira grave, a saúde pública ou o meio ambiente;

d) concorrendo para danos à propriedade alheia;

e) atingindo áreas de unidades de conservação ou áreas sujeitas, por ato do Poder Público, a regime especial de uso;

f) atingindo áreas urbanas ou quaisquer assentamentos humanos;

g) em período de defeso à fauna;

h) em domingos ou feriados;

i) à noite; 
j) em épocas de seca ou inundações;

I) no interior do espaço territorial especialmente protegido;

m) com o emprego de métodos cruéis para abate ou captura de animais;

n) mediante fraude ou abuso de confiança;

o) mediante abuso do direito de licença, permissão ou autorização ambiental;

p) no interesse de pessoa jurídica mantida, total ou parcialmente, por verbas públicas ou beneficiada por incentivos fiscais;

q) atingindo espécies ameaçadas, listadas em relatórios oficiais das autoridades competentes;

r) facilitada por funcionário público no exercício de suas funções.

Art 16. Nos crimes previstos nesta Lei, a suspensão condicional da pena pode ser aplicada nos casos de condenação a pena privativa de liberdade não superior a três anos.

Art 17. A verificação da reparação a que se refere o $\S 2^{\circ}$ do art. 78 do Código Penal será feita mediante laudo de reparação do dano ambiental, e as condições a serem impostas pelo juiz deverão relacionar-se com a proteção ao meio ambiente.

Art 18. A multa será calculada segundo os critérios do Código Penal; se revelarse ineficaz, ainda que aplicada no valor máximo, poderá ser aumentada até três vezes, tendo em vista o valor da vantagem econômica auferida.

Art 19. A perícia de constatação do dano ambiental, sempre que possível, fixará o montante do prejuízo causado para efeitos de prestação de fiança e cálculo de multa.

Parágrafo único. A perícia produzida no inquérito civil ou no juízo cível poderá ser aproveitada no processo penal, instaurando-se o contraditório.

Art 20. A sentença penal condenatória, sempre que possível, fixará o valor mínimo para reparação dos danos causados pela inflação, considerando os prejuízos sofridos pelo ofendido ou pelo meio ambiente.

Parágrafo único. Transitada em julgado a sentença condenatória, a execução poderá efetuar-se pelo valor fixado nos termos do caput, sem prejuízo da liquidação para apuração do dano efetivamente sofrido.

Art 21. As penas aplicáveis isolada, cumulativa ou alternativamente às pessoas jurídicas, de acordo com o disposto no art. $3^{\circ}$, são:

I - multa; 
II - restritivas de direitos;

III - prestação de serviços à comunidade.

Art 22. As penas restritivas de direitos da pessoas jurídica são:

I - suspensão parcial ou total de atividades;

II - interdição temporária de estabelecimento, obra ou atividade;

III - proibição de contratar com o Poder Público, bem como dele obter subsídios, subvenções ou doações. $<p>\S 1^{\circ} \mathrm{A}$ suspensão de atividades será aplicada quando estas não estiverem obedecendo às disposições legais ou regulamentares, relativas à proteção do meio ambiente.

$\S 2^{\circ} \mathrm{A}$ interdição será aplicada quando o estabelecimento, obra ou atividade estiver funcionando sem a devida autorização, ou em desacordo com a concedida, ou com violação de disposição legal ou regulamentar.

$\S 3^{\circ} \mathrm{A}$ proibição de contratar com o Poder Público e dele obter subsídios, subvenções ou doações não poderá exceder o prazo de dez anos.

Art 23. A prestação de serviços à comunidade pela pessoa jurídica consistirá em:

I - custeio de programas e de projetos ambientais;

II - execução de obras de recuperação de áreas degradadas;

III - manutenção de espaços públicos;

IV - contribuições a entidades ambientais ou culturais públicas.

Art 24. A pessoa jurídica constituída ou utilizada, preponderantemente, com o fim de permitir, facilitar ou ocultar a prática de crime definido nesta Lei terá decretada sua liquidação forçada, seu patrimônio será considerado instrumento do crime e como tal perdido em favor do Fundo Penitenciário Nacional.

\section{CAPÍTULO III}

\section{DA APREENSÃO DO PRODUTO E DO INSTRUMENTO DE INFRAÇÃO}

\section{ADMINISTRATIVA OU DE CRIME}

Art 25. Verificada a infração, serão apreendidas seus produtos e instrumentos, lavrando-se os respectivos autos.

$\S 1^{\circ}$ Os animais serão libertados em seu habitat ou entregues a jardins zoológicos, fundações ou entidades assemelhadas, desde que fiquem sob a responsabilidade de técnicos habilitados. 
$\S 2^{\circ}$ Tratando-se de produtos perecíveis ou madeiras, serão estes avaliados e doados a instituições científicas, hospitalares, penais e outras com fins beneficentes.

$\S 3^{\circ}$ Os produtos e subprodutos da fauna não perecíveis serão destruídos ou doados a instituições científicas, culturais ou educacionais.

$\S 4^{\circ}$ Os instrumentos utilizados na prática da infração serão vendidos, garantida a sua descaracterização por meio da reciclagem.

\section{CAPÍTULO IV}

\section{DA AÇÃO E DO PROCESSO PENAL}

Art 26. Nas infrações penais previstas nesta Lei, a ação penal é pública incondicionada.

\section{Parágrafo único. (VETADO)}

Art 27. Nos crimes ambientais de menor potencial ofensivo, a proposta de aplicação imediata de pena restritiva de direitos ou multa, prevista no art. 76 da Lei $n^{\circ}$ 9.099, de 26 de setembro de 1995, somente poderá ser formulada desde que tenha havido a prévia composição do dano ambiental, de que trata o art. 74 da mesma lei, salvo em caso de comprovada impossibilidade.

Art 28. As disposições do art. 89 da Lei no 9.099, de 26 de setembro de 1995, aplicam-se aos crimes de menor potencial ofensivo definidos nesta Lei, com as seguintes modificações:

I - a declaração de extinção de punibilidade, de que trata o $\S 5^{\circ}$ do artigo referido no caput, dependerá de laudo de constatação de reparação do dano ambiental, ressalvada a impossibilidade prevista no inciso I do $\S 1^{\circ}$ do mesmo artigo;

II - na hipótese de o laudo de constatação comprovar não ter sido completa a reparação, o prazo de suspensão do processo será prorrogado, até o período máximo previsto no artigo referido no caput, acrescido de mais um ano, com suspensão do prazo da prescrição;

III - no período de prorrogação, não se aplicarão as condições dos incisos II, III e IV do $\S 1^{\circ}$ do artigo mencionado no caput;

IV - findo o prazo de prorrogação, proceder-se-á à lavratura de novo laudo de constatação de reparação do dano ambiental, podendo, conforme seu resultado, ser novamente prorrogado o período de suspensão, até o máximo previsto no inciso II deste artigo, observado o disposto no inciso III;

V - esgotado o prazo máximo de prorrogação, a declaração de extinção de punibilidade dependerá de laudo de constatação que comprove ter o acusado tomado as providências necessárias à reparação integral do dano. 


\section{CAPÍTULO V}

DOS CRIMES CONTRA O MEIO AMBIENTE

\section{SEÇÃO I}

\section{Dos Crimes contra a Fauna}

Art 29. Matar, perseguir, caçar, apanhar, utilizar espécimes da fauna silvestre, nativos ou em rota migratória, sem a devida permissão, licença ou autorização da autoridade competente, ou em desacordo com a obtida:

Pena - detenção de seis meses a um ano, e multa.

$\S 1^{\circ}$ Incorre nas mesmas penas:

I - quem impede a procriação da fauna, sem licença, autorização ou em desacordo com a obtida;

II - quem modifica, danifica ou destrói ninho, abrigo ou criadouro natural;

III - quem vende, expõe à venda, exporta ou adquire, guarda, tem em cativeiro ou depósito, utiliza ou transporta ovos, larvas ou espécimes da fauna silvestre, nativa ou em rota migratória, bem como produtos e objetos dela oriundos, provenientes de criadouros não autorizadas ou sem a devida permissão, licença ou autorização da autoridade competente.

$\S 2^{\circ}$ No caso de guarda doméstica de espécie silvestre não considerada ameaçada de extinção, pode o juiz, considerando as circunstâncias, deixar de aplicar a pena.

$\S 3^{\circ}$ São espécimes da fauna silvestre todos aqueles pertencentes às espécies nativas, migratória e quaisquer outras, aquáticas ou terrestres, que tenham todo ou parte de seu ciclo de vida ocorrendo dentro dos limites do território brasileiro, ou águas jurisdicionais brasileiras.

$\S 4^{\circ} \mathrm{A}$ pena é aumentada de metade, se o crime é praticado:

I - contra espécie rara ou considerada ameaçada de extinção, ainda que somente no local da infração;

II - em período proibido à caça;

III - durante a noite;

IV - com abuso de licença;

V - em unidade de conservação; 
VI - com emprego de métodos ou instrumentos capazes de provocar destruição em massa.

$\S 5^{\circ}$ A pena é aumentada até o triplo, se o crime decorre do exercício de caça profissional;

$\S 6^{\circ}$ As disposições deste artigo não se aplicam aos atos de pesca.

Art 30. Exportar para o exterior peles e couros de anfíbios e répteis em bruto, sem a autorização da autoridade ambiental competente:

Pena - reclusão, de um a três anos, e multa.

Art 31. Introduzir espécime animal no País, sem parecer técnico oficial favorável e licença expedida por autoridade competente:

Pena - detenção, de três meses a um ano, e multa.

Art 32. Praticar ato de abuso, maus-tratos, ferir ou mutilar animais silvestres, domésticos ou domesticados, nativos ou exóticos:

Pena - detenção, de três meses a um ano, e multa.

$\S 1^{\circ}$ Incorre nas mesmas penas quem realiza experiência dolorosa ou cruel em animal vivo, ainda que para fins didáticos ou científicos, quando existirem recursos alternativos.

$\S 2^{\circ} \mathrm{A}$ pena é aumentada de um sexto a um terço, se ocorre morte do animal.

Art 33. Provocar, pela emissão de efluentes ou carreamento de materiais, o perecimento de espécimes da fauna aquática existentes em rios, lagos, açudes, lagoas, baías ou águas jurisdicionais brasileiras:

Pena - detenção, de um a três anos, ou multa, ou ambas cumulativamente.

Parágrafo único. Incorre nas mesmas penas:

I - quem causa degradação em viveiros, açudes ou estações de aqüicultura de domínio público;

II - quem explora campos naturais de invertebrados aquáticos e algas, sem licença, permissão ou autorização da autoridade competente;

III - quem fundeia embarcações ou lança detritos de qualquer natureza sobre bancos de moluscos ou corais, devidamente demarcados em carta náutica.

Art 34. Pescar em período no qual a pesca seja proibida ou em lugares interditados por órgão competente: 
Pena - detenção de um ano a três anos ou multa, ou ambas as penas cumulativamente.

Parágrafo único. Incorre nas mesmas penas quem:

I - pesca espécies que devam ser preservadas ou espécimes com tamanhos inferiores aos permitidos;

II - pesca quantidades superiores às permitidas, ou mediante a utilização de aparelhos, petrechos, técnicas e métodos não permitidos;

III - transporta, comercializa, beneficia ou industrializa espécimes provenientes da coleta, apanha e pesca proibidas.

Art. 35. Pescar mediante a utilização de:

I - explosivos ou substâncias que, em contato com a água, produzam efeito semelhante;

II - substâncias tóxicas, ou outro meio proibido pela autoridade competente:

Pena - reclusão de um ano a cinco anos.

Art 36. Para os efeitos desta Lei, considera-se pesca todo ato tendente a retirar, extrair, coletar, apanhar, apreender ou capturar espécimes dos grupos dos peixes, crustáceos, moluscos e vegetais hidróbios, suscetíveis ou não de aproveitamento econômico, ressalvadas as espécies ameaçadas de extinção, constantes nas listas oficiais da fauna e da flora.

Art. 37. Não é crime o abate de animal, quando realizado:

I - em estado de necessidade, para saciar a fome do agente ou de sua família;

II - para proteger lavouras, pomares e rebanhos da ação predatória ou destruidora de animais, desde que legal e expressamente autorizado pela autoridade competente;

III - (VETADO)

IV - por ser nocivo o animal, desde que assim caracterizado pelo órgão competente.

\section{SEÇÃO II}

Dos Crimes contra a Flora

Art 38. Destruir ou danificar floresta considerada de preservação permanente, mesmo que em formação, ou utilizá-la com infringência das normas de proteção: 
Pena - detenção, de um a três anos, ou multa, ou ambas as penas cumulativamente.

Parágrafo único. Se o crime for culposo, a pena será reduzida à metade.

Art 39. Cortar árvores em floresta considerada de preservação permanente, sem permissão da autoridade competente:

Pena - detenção, de um a três anos, ou multa, ou ambas as penas cumulativamente.

Art 40. Causar dano direto ou indireto às Unidades de Conservação e às áreas de que trata 0 art. 27 do Decreto $\mathrm{n}^{\circ}$ 99.274, de 6 de junho de 1990, independentemente de sua localização:

Pena - reclusão, de um a cinco anos.

$\S 1^{\circ}$ Entende-se por Unidades de Conservação as Reservas Biológicas, Reservas Ecológicas, Estações Ecológicas, Parques Nacionais, Estaduais e Municipais, Florestas Nacionais, Estaduais e Municipais, Áreas de Proteção Ambiental, Áreas de Relevante Interesse Ecológico e Reservas Extrativistas ou outras a serem criadas pelo Poder Público.

$\S 2^{\circ}$ A ocorrência de dano afetando espécies ameaçadas de extinção no interior das Unidades de Conservação será considerada circunstância agravante para a fixação da pena.

$\S 3^{\circ}$ Se o crime for culposo, a pena será reduzida à metade.

Art. 41. Provocar incêndio em mata ou floresta:

Pena - reclusão, de dois a quatro anos, e multa.

Parágrafo único. Se o crime é culposo, a pena é de detenção de seis meses a um ano, e multa.

Art 42. Fabricar, vender, transportar ou soltar balões que possam provocar incêndios nas florestas e demais formas de vegetação, em áreas urbanas ou qualquer tipo de assentamento humano:

Pena - detenção de um a três anos ou multa, ou ambas as penas cumulativamente.

Art. 43. (VETADO)

Art 44. Extrair de florestas de domínio público ou consideradas de preservação permanente, sem prévia autorização, pedra, areia, cal ou qualquer espécie de minerais:

Pena - detenção, de seis meses a um ano, e multa. 
Art 45. Cortar ou transformar em carvão madeira de lei, assim classificada por ato do Poder Público, para fins industriais, energéticos ou para qualquer outra exploração, econômica ou não, em desacordo com as determinações legais:

Pena - reclusão, de um a dois anos, e multa.

Art 46. Receber ou adquirir, para fins comerciais ou industriais, madeira, lenha, carvão e outros produtos de origem vegetal, sem exigir a exibição de licença do vendedor, outorgada pela autoridade competente, e sem munir-se da via que deverá acompanhar o produto até final beneficiamento:

Pena - detenção, de seis meses a um ano, e multa.

Parágrafo único. Incorre nas mesmas penas quem vende, expõe à venda, tem em depósito, transporta ou guarda madeira, lenha, carvão e outros produtos de origem vegetal, sem licença válida para todo o tempo da viagem ou do armazenamento, outorgada pela autoridade competente.

Art 47. (VETADO)

Art 48. Impedir ou dificultar a regeneração natural de florestas e demais formas de vegetação.

Pena - detenção, de seis meses a um ano, e multa.

Art 49. Destruir, danificar, lesar ou maltratar, por qualquer modo ou meio, plantas de ornamentação de logradouros públicos ou em propriedade privada alheia:

Pena - detenção, de três meses a um ano, ou multa, ou ambas as penas cumulativamente.

Parágrafo único. No crime culposo, a pena é de um a seis meses, ou multa.

Art 50. Destruir ou danificar florestas nativas ou plantadas ou vegetação fixadora de dunas protetora de mangues, objeto de especial preservação:

Pena - detenção, de três meses a um ano e multa.

Art 51. Comercializar motosserra ou utilizá-la em florestas e nas demais formas de vegetação, sem licença ou registro da autoridade competente:

Pena - detenção, de três meses a um ano, e multa.

Art 52. Penetrar em Unidades de Conservação conduzindo substâncias ou instrumentos próprios para caça ou para exploração de produtos ou subprodutos florestais, sem licença da autoridade competente:

Pena - detenção, de seis meses a um ano, e multa. 
Art 53. Nos crimes previstos nesta Seção, a pena é aumentada de um sexto a um terço se:

I - do fato resulta a diminuição de águas naturais, a erosão do solo ou a modificação do regime climático;< p> II - o crime é cometido:

a) no período de queda das sementes;

b) no período de formação de vegetações;

c) contra espécies raras ou ameaçadas de extinção, ainda que a ameaça ocorra somente no local da infração;

d) em época de seca ou inundação;

e) durante a noite, em domingo ou feriado.

\section{SEÇÃO III}

Da Poluição e outros Crimes Ambientais

Art 54. Causar poluição de qualquer natureza em níveis tais que resultem ou possam resultar em danos à saúde humana, ou que provoquem a mortandade de animais ou a destruição significativa da flora:

Pena - reclusão, de um a quatro anos, e multa.

$\S 1^{\circ}$ Se o crime é culposo:

Pena - detenção, de seis meses a um ano, e multa.

$\S 2^{\circ}$ Se o crime:

I - tomar uma área, urbana ou rural, imprópria para a ocupação humana;

II - causar poluição atmosférica que provoque a retirada, ainda que momentânea, dos habitantes das áreas afetadas, ou que cause danos diretos à saúde da população;

III - causar poluição hídrica que torne necessária a interrupção do abastecimento público de água de uma comunidade;

IV - dificultar ou impedir o uso público das praias;

V - ocorrer por lançamento de resíduos sólidos, líquidos ou gasosos, ou detritos, óleos ou substâncias oleosas, em desacordo com as exigências estabelecidas em leis ou regulamentos:

Pena - reclusão, de um a cinco anos. 
$\S 3^{\circ}$ Incorre nas mesmas penas previstas no parágrafo anterior quem deixar de adotar, quando assim o exigir a autoridade competente, medidas de precaução em caso de risco de dano ambiental grave ou irreversível.

Art 55. Executar pesquisa, lavra ou extração de recursos minerais sem a competente autorização, permissão, concessão ou licença, ou em desacordo com a obtida:

Pena - detenção, de seis meses a um ano, e multa.

Parágrafo único. Nas mesmas penas incorre quem deixa de recuperar a área pesquisada ou explorada, nos termos da autorização, permissão, licença, concessão ou determinação do órgão competente.

Art 56. Produzir, processar, embalar, importar, exportar, comercializar, fornecer, transportar, armazenar, guardar, ter em depósito ou usar produto ou substância tóxica, perigosa ou nociva à saúde humana ou ao meio ambiente, em desacordo com as exigências estabelecidas em leis ou nos seus regulamentos:

Pena - reclusão, de um a quatro anos, e multa.

$\S 1^{\circ}$ Nas mesmas penas incorre quem abandona os produtos ou substâncias referidos no caput, ou os utiliza em desacordo com as normas de segurança.

$\S 2^{\circ}$ Se o produto ou a substância for nuclear ou radioativa, a pena é aumentada de um sexto a um terço.

$\S 3^{\circ}$ Se o crime é culposo:

Pena - detenção, de seis meses a um ano, e multa.

Art. 57. (VETADO)

Art 58. Nos crimes dolosos previstos nesta Seção, as penas serão aumentadas:

I - de um sexto a um terço, se resulta dano irreversível à flora ou ao meio ambiente em geral;

II - de um terço até a metade, se resulta lesão corporal de natureza grave em outrem;

III - até o dobro, se resultar a morte de outrem.

Parágrafo único. As penalidades previstas neste artigo somente serão aplicadas se do fato não resultar crime mais grave.

Art. 59. (VETADO)

Art 60. Construir, reformar, ampliar, instalar ou fazer funcionar, em qualquer parte do território nacional, estabelecimentos, obras ou serviços potencialmente 
poluidores, sem licença ou autorização dos órgãos ambientais competentes, ou contrariando as normas legais e regulamentares pertinentes:

Pena - detenção, de um a seis meses ou multa, ou ambas as penas cumulativamente.

Art 61. Disseminar doença ou praga ou espécies que possam causar dano à agricultura, à pecuária, à fauna, à flora ou aos ecossistemas:

Pena - reclusão, de um a quatro anos, e multa.

\section{SEÇÃO IV}

\section{Dos Crimes contra o Ordenamento Urbano e o Patrimônio Cultural}

Art 62. Destruir, inutilizar ou deteriorar:

I - bem especialmente protegido por lei, ato administrativo ou decisão judicial;

II - arquivo, registro, museu, biblioteca, pinacoteca, instalação científica ou similar protegido por lei, ato administrativo ou decisão judicial:

Pena - reclusão, de um a três anos, e multa.

Parágrafo único. Se o crime for culposo, a pena é de seis meses a um ano de detenção, sem prejuízo da multa.

Art 63. Alterar o aspecto ou estrutura de edificação ou local especialmente protegido por lei, ato administrativo ou decisão judicial, em razão de seu valor paisagístico, ecológico, turístico, artístico, histórico, cultural, religioso, arqueológico, etnográfico ou monumental, sem autorização da autoridade competente ou em desacordo com a concedida:

Pena - reclusão, de um a três anos, e multa.

Art 64. Promover construção em solo não edificável, ou no seu entorno, assim considerado em razão de seu valor paisagístico, ecológico, artístico, turístico, histórico, cultural, religioso, arqueológico, etnográfico ou monumental, sem autorização da autoridade competente ou em desacordo com a concedida:

Pena - detenção, de seis meses a um ano, e multa.

Art 65. Pichar, grafitar ou por outro meio conspurcar edificação ou monumento urbano:

Pena - detenção, de três meses a um ano, e multa.

Parágrafo único. Se o ato for realizado em monumento ou coisa tombada em virtude do seu valor artístico, arqueológico ou histórico, a pena é de seis meses a um ano de detenção, e multa. 


\section{SEÇÃO V}

Dos Crimes contra a Administração Ambiental

Art 66. Fazer o funcionário público afirmação falsa ou enganosa, omitir a verdade, sonegar informações ou dados técnico-científicos em procedimentos de autorização ou de licenciamento ambiental:

Pena - reclusão, de um a três anos, e multa.

Art 67. Conceder o funcionário público licença, autorização ou permissão em desacordo com as normas ambientais, para as atividades, obras ou serviços cuja realização depende de ato autorizativo do Poder Público:

Pena - detenção, de um a três anos, e multa.

Parágrafo único. Se o crime é culposo, a pena é de três meses a um ano de detenção, sem prejuízo da multa.

Art 68. Deixar, aquele que tiver o dever legal ou contratual de fazê-lo, de cumprir obrigação de relevante interesse ambiental:

Pena - detenção, de um a três anos, e multa.

Parágrafo único. Se o crime é culposo, a pena é de três meses a um ano, sem prejuízo da multa.

Art 69. Obstar ou dificultar a ação fiscalizadora do Poder Público no trato de questões ambientais:

Pena - detenção, de um a três anos, e multa.

\section{CAPÍTULO VI}

\section{DA INFRAÇÃO ADMINISTRATIVA}

Art 70. Considera-se infração administrativa ambiental toda ação ou omissão que viole as regras jurídicas de uso, gozo, promoção, proteção e recupeção do meio ambiente.

$\S 1^{\circ}$ São autoridades competentes para lavrar auto de infração ambiental e instaurar processo administrativo os funcionários de órgãos ambientais integrantes do Sistema Nacional de Meio Ambiente - SISNAMA, designados para as atividades de fiscalização, bem como os agentes das Capitanias dos Portos, do Ministério da Marinha.

$\S 2^{\circ}$ Qualquer pessoa, constatando infração ambiental, poderá dirigir representação às autoridades relacionadas no parágrafo anterior, para efeito do exercício do seu poder de polícia. 
$\S 3^{\circ} \mathrm{A}$ autoridade ambiental que tiver conhecimento de infração ambiental é obrigada a promover a sua apuração imediata, mediante processo administrativo próprio, sob pena de co-responsabilidade.

$\S 4^{\circ}$ As infrações ambientais são apuradas em processo administrativo próprio, assegurado o direito de ampla defesa e o contraditório, observadas as disposições desta Lei.

Art 71. O processo administrativo para apuração de infração ambiental deve observar os seguintes prazos máximos:

I - vinte dias para o infrator oferecer defesa ou impugnação contra o auto de infração, contados da data da ciência da autuação;

II - trinta dias para a autoridade competente julgar o auto de infração, contados da data da sua lavratura, apresentada ou não a defesa ou impugnação;

III - vinte dias para o infrator recorrer da decisão condenatória à instância superior do Sistema Nacional do Meio Ambiente - SISNAMA, ou à Diretoria de Portos e Costas, do Ministério da Marinha, de acordo com o tipo de autuação;

IV - cinco dias para o pagamento de multa, contados da data do recebimento da notificação.

Art 72. As infrações administrativas são punidas com as seguintes sanções, observado o disposto no art. $6^{\circ}$ :

I - advertência;

II - multa simples;

III - multa diária;

IV - apreensão dos animais, produtos e subprodutos da fauna e flora, instrumentos, petrechos, equipamentos ou veículos de qualquer natureza utilizados na infração;

V - destruição ou inutilização do produto;

VI - suspensão de venda e fabricação do produto;

VII - embargo de obra ou atividade;

VIII - demolição de obra;

IX - suspensão parcial ou total de atividades;

$X-(\operatorname{VETADO})$

$\mathrm{XI}$ - restritiva de direitos. 
$\S 1^{\circ}$ Se o infrator cometer, simultaneamente, duas ou mais infrações, ser-lhe-ão aplicadas, cumulativamente, as sanções a elas cominadas.

$\S 2^{\circ} \mathrm{A}$ advertência será aplicada pela inobservância das disposições desta Lei e da legislação em vigor, ou de preceitos regulamentares, sem prejuízo das demais sanções previstas neste artigo.

$\S 3^{\circ} \mathrm{A}$ multa simples será aplicada sempre que o agente, por negligência ou dolo:

I - advertido por irregularidades que tenham sido praticadas, deixar de saná-las, no prazo assinalado por órgão competente do SISNAMA ou pela Capitania dos Portos, do Ministério da Marinha;

II - opuser embaraço à fiscalização dos órgãos do SISNAMA ou da Capitania dos Portos, do Ministério da Marinha.

$\S 4^{\circ} \mathrm{A}$ multa simples pode ser convertida em serviços de preservação, melhoria e recuperação da qualidade do meio ambiente.

$\S 5^{\circ} \mathrm{A}$ multa diária será aplicada sempre que o cometimento da infração se prolongar no tempo.

$\S 6^{\circ} \mathrm{A}$ apreensão e destruição referidas nos incisos IV e $\mathrm{V}$ do caput obedecerão ao disposto no art. 25 desta Lei.

$\S 7^{\circ}$ As sanções indicadas nos incisos $\mathrm{VI}$ a IX do caput serão aplicadas quando o produto, a obra, a atividade ou o estabelecimento não estiverem obedecendo às prescrições legais ou regulamentares.

$\S 8^{\circ}$ As sanções restritivas de direito são:

I - suspensão de registro, licença ou autorização;

II - cancelamento de registro, licença ou autorização;

III - perda ou restrição de incentivos e benefícios fiscais;

IV - perda ou suspensão da participação em linhas de financiamento em estabelecimentos oficiais de crédito;

V - proibição de contratar com a Administração Pública, pelo período de até três anos.

Art 73. Os valores arrecadados em pagamento de multas por infração ambiental serão revertidos ao Fundo Nacional do Meio Ambiente, criado pela Lei $n^{\circ} 7.797$, de 10 de julho de 1989, Fundo Naval, criado pelo Decreto $n^{\circ} 20.923$, de 8 de janeiro de 1932, fundos estaduais ou municipais de meio ambiente, ou correlatos, conforme dispuser o órgão arrecadador. 
Art 74. A multa terá por base a unidade, hectare, metro cúbico, quilograma ou outra medida pertinente, de acordo com o objeto jurídico lesado.

Art 75. O valor da multa de que trata este Capítulo será fixado no regulamento desta Lei e corrigido periodicamente, com base nos índices estabelecidos na legislação pertinente, sendo o mínimo de $\mathrm{R} \$ 50,00$ (cinqüenta reais) e o máximo de $R \$ 50.000 .000,00$ (cinqüenta milhões de reais).

Art 76. O pagamento de multa imposta pelos Estados, Municípios, Distrito Federal ou Territórios substitui a multa federal na mesma hipótese de incidência.

\section{CAPÍTULO VII}

DA COOPERAÇÃO INTERNACIONAL PARA A PRESERVAÇÃO DO MEIO AMBIENTE

Art 77. Resguardados a soberania nacional, a ordem pública e os bons costumes, - Governo brasileiro prestará, no que concerne ao meio ambiente, a necessária cooperação a outro país, sem qualquer ônus, quando solicitado para:

I - produção de prova;

II - exame de objetos e lugares;

III - informações sobre pessoas o coisas;

IV - presença temporária da pessoa presa, cujas declarações tenham relevância para a decisão de uma causa;

$\mathrm{V}$ - outras formas de assistência permitidas pela legislação em vigor ou pelos tratados de que o Brasil seja parte.

$\S 1^{\circ} \mathrm{A}$ solicitação de que trata este artigo será dirigida ao Ministério da Justiça que a remeterá, quando necessário, ao órgão judiciário competente para decidir a seu respeito, ou a encaminhará à autoridade capaz de atendê-la.

$\S 2^{\circ} \mathrm{A}$ solicitação deverá conter:

I - o nome e a qualificação da autoridade solicitante;

II - o objeto e o motivo de sua formulação;

III - a descrição sumária do procedimento em curso no país solicitante;

IV - a especificação da assistência solicitada;

V - a documentação indispensável ao seu esclarecimento, quando for o caso.

Art 78. Para a consecução dos fins visados nesta Lei e especialmente para a reciprocidade da cooperação internacional, deve ser mantido sistema de 
comunicações apto a facilitar o intercâmbio rápido e seguro de informações com órgãos de outros países.

\section{CAPÍTULO VIII}

DISPOSIÇÕES FINAIS

Art 79. Aplicam-se subsidiariamente a esta Lei as disposições do Código Penal e do Código de Processo Penal.

Art 80. O Poder Executivo regulamentará esta Lei no prazo de noventa dias a contar de sua publicação.

Art. 81. (VETADO)

Art. 82. Revogam-se as disposições em contrário.

Brasília, 12 de fevereiro de $1998 ; 177^{\circ}$ da Independência e $110^{\circ}$ da República.

\section{FERNANDO HENRIQUE CARDOSO}

Gustavo Krause

\section{RETIFICAÇÃO}

No D.O. no 31, de 13-2-98, Seção 1, pág. 1, ONDE SE LÊ: Lei № 9.605, DE FEVEREIRO DE 1998, LEIA-SE: LEI № 9.605, DE 12 DE FEVEREIRO DE 1998. 


\section{ANEXO II}

DECRETO No 4.653, DE 27 DE MARÇO DE 2003.

Aprova a Estrutura Regimental e o Quadro Demonstrativo dos Cargos em Comissão e das Funções Gratificadas do Ministério do Turismo, e dá outras providências.

O PRESIDENTE DA REPÚBLICA, no uso das atribuições que the confere o art. 84, incisos IV e VI, alínea "a", da Constituição, e tendo em vista o disposto nos arts. 47 e 50 da Medida Provisória $n^{\circ} 103$, de $1^{\circ}$ de janeiro de 2003,

\section{DECRETA:}

Art. $1^{\circ}$ Ficam aprovados a Estrutura Regimental e o Quadro Demonstrativo dos Cargos em Comissão e das Funções Gratificadas do Ministério do Turismo, na forma dos Anexos I e II a este Decreto.

Art. $2^{\circ} \mathrm{Em}$ decorrência do disposto no art. $1^{\circ}$, ficam remanejados, na forma do Anexo III a este Decreto, da Secretaria de Gestão, do Ministério do Planejamento, Orçamento e Gestão, provenientes da reorganização dos órgãos e entidades da Administração Pública federal, para o Ministério do Turismo os seguintes cargos em comissão do Grupo-Direção e Assessoramento Superiores DAS e Funções Gratificadas - FG: dois DAS 101.6; dez DAS 101.5; vinte e seis DAS 101.4; vinte e cinco DAS 101.3; três DAS 101.2; quatro DAS 102.5; cinco DAS 102.4; dois DAS 102.3; vinte e cinco DAS 102.2; vinte e três DAS 102.1; cinco FG-1; cinco FG-2 e cinco FG-3.

Art. $3^{\circ} \mathrm{O}$ regimento interno dos órgãos do Ministério do Turismo será aprovado pelo Ministro de Estado do Turismo e publicado no Diário Oficial da União, no prazo de noventa dias, contado da data de publicação deste Decreto.

Art. $4^{\circ}$ Este Decreto entra em vigor na data de sua publicação.

República.

Brasília, 27 de março de 2003; $182^{\circ}$ da Independência e $115^{\circ}$ da

LUIZ INÁCIO LULA DA SILVA

Guido Mantega Neto

Walfrido Silvino dos Mares Guia 


\section{ESTRUTURA REGIMENTAL DO MINISTÉRIO DO TURISMO}

\section{CAPÍTULO I}

DA NATUREZA E COMPETÊNCIA

Art. $1^{\circ} \mathrm{O}$ Ministério do Turismo, órgão da administração direta, tem como área de competência os seguintes assuntos:

I - política nacional de desenvolvimento do turismo;

II - promoção e divulgação do turismo nacional, no País e no exterior;

III - estímulo às iniciativas públicas e privadas de incentivo às atividades turísticas; $\mathrm{e}$

IV - planejamento, coordenação, supervisão e avaliação dos planos e programas de incentivo ao turismo.

\section{CAPÍTULO II}

DA ESTRUTURA ORGANIZACIONAL

Art. $2^{\circ} \mathrm{O}$ Ministério do Turismo tem a seguinte Estrutura Organizacional:

I - órgãos de assistência direta e imediata ao Ministro de Estado:

a) Gabinete;

b) Secretaria-Executiva: Subsecretaria de Planejamento, Orçamento e Administração; e

c) Consultoria Jurídica;

II - órgãos específicos singulares:

a) Secretaria de Políticas de Turismo:

1. Departamento de Planejamento e Avaliação do Turismo;

2. Departamento de Relações Institucionais; e

3. Departamento de Relações Internacionais;

b) Secretaria de Programas de Desenvolvimento do Turismo:

1. Departamento de Programas Regionais de Desenvolvimento;

2. Departamento de Promoção de Investimentos no Turismo; e

3. Departamento da Produção Associada ao Turismo; 
III - órgão colegiado: Conselho Nacional de Turismo - CNT; e

IV - entidade vinculada: EMBRATUR - Instituto Brasileiro de Turismo.

\section{CAPÍTULO III}

DA COMPETÊNCIA DOS ÓRGÃOS

Seção I

Dos Órgãos de Assistência Direta e Imediata ao Ministro de Estado

Art. $3^{\circ}$ Ao Gabinete do Ministro compete:

I - assistir ao Ministro de Estado em sua representação política e social, ocupar-se das relações públicas e do preparo e despacho do seu expediente pessoal;

II - promover a articulação entre o Ministério e os órgãos que compõem a Presidência da República;

III - providenciar o atendimento às consultas e aos requerimentos formulados pelo Congresso Nacional e acompanhar o andamento dos projetos, em tramitação, de interesse ministerial;

IV - providenciar a publicação oficial e a divulgação das matérias relacionadas com a área de atuação do Ministério; e

$\mathrm{V}$ - planejar, coordenar e supervisionar o desenvolvimento das atividades de comunicação social do Ministério.

Art. $4^{\circ}$ À Secretaria-Executiva compete:

I - assistir ao Ministro de Estado na supervisão e coordenação das atividades das Secretarias integrantes da estrutura do Ministério;

II - supervisionar e coordenar a execução das atividades relacionadas com os Sistemas Federais de Planejamento e de Orçamento, de Administração Financeira, de Contabilidade, de Organização e Modernização Administrativa, de Administração dos Recursos de Informação e Informática, de Pessoal Civil e de Serviços Gerais, no âmbito do Ministério; e

III - auxiliar o Ministro de Estado na definição das diretrizes e na implementação das políticas e ações da área de competência do Ministério.

Parágrafo único. A Secretaria Executiva exerce, ainda, o papel de órgão setorial dos Sistemas de Pessoal Civil da Administração Federal - SIPEC, de Organização e Modernização Administrativa - SOMAD, de Administração de Recursos de Informação e Informática-SISP, de Serviços Gerais - SISG, de Planejamento e de Orçamento Federal e de Contabilidade, por intermédio da Subsecretaria de Planejamento, Orçamento e Administração, a ela subordinada. compete:

Art. $5^{\circ}$ À Subsecretaria de Planejamento, Orçamento e Administração

I - planejar, coordenar e supervisionar a execução das atividades relacionadas com os Sistemas Federais de Planejamento e de Orçamento, de Administração Financeira de Organização e Modernização Administrativa, de 
Contabilidade, de Informação e Informática, de Recursos Humanos e de Serviços Gerais, no âmbito do Ministério;

II - promover a articulação com os órgãos centrais dos sistemas federais, referidos no inciso anterior e informar e orientar os órgãos do Ministério quanto ao cumprimento das normas administrativas estabelecidas;

III - promover e coordenar a elaboração e consolidação dos planos e programas das atividades de sua área de competência e submetê-los à decisão superior;

IV - desenvolver as atividades de execução orçamentária, financeira e contábil, no âmbito do Ministério;

$\mathrm{V}$ - analisar e avaliar as prestações de contas, parciais ou finais, quanto aos seus aspectos técnicos e financeiros, propondo a instauração de tomada de contas especial e demais medidas de sua competência quando a prestação de contas não for aprovada, após exauridas as providências cabíveis; e

$\mathrm{VI}$ - realizar tomadas de contas dos ordenadores de despesa e demais responsáveis por bens e valores públicos e de todo aquele que der causa a perda, extravio ou outra irregularidade que resulte em dano ao erário.

Art. $6^{\circ}$ À Consultoria Jurídica, órgão setorial da Advocacia-Geral da União, compete: $/ p>$

I - assessorar o Ministro de Estado em assuntos de natureza jurídica;<

II - exercer a coordenação das atividades jurídicas do Ministério e da entidade a ele vinculada;

III - fixar a interpretação da Constituição, das leis, dos tratados e dos demais atos normativos a ser uniformemente seguida em suas áreas de atuação e coordenação, quando não houver orientação normativa do Advogado-Geral da União; de Estado;

IV - elaborar estudos e preparar informações, por solicitação do Ministro

V - assistir ao Ministro de Estado no controle interno da legalidade administrativa, dos atos por ele praticados ou já efetivados e daqueles oriundos de órgãos ou entidades sob sua coordenação;

$\mathrm{VI}$ - examinar, prévia e conclusivamente, no âmbito do Ministério:

a) os textos de editais de licitação, bem como os dos respectivos contratos ou instrumentos congêneres, a serem publicados e celebrados;

b) os atos pelos quais se vá reconhecer a inexigibilidade ou decidir a dispensa de licitação; $e</ p>$

c) propostas, estudos, projetos, anteprojetos e minutas de atos normativos de interesse do Ministério.

Seção II

Dos Órgãos Específicos Singulares 
Art. $7^{\circ}$ À Secretaria de Políticas de Turismo compete:

I - subsidiar a formulação, elaboração e monitorar a Política Nacional de Turismo, de acordo com as diretrizes propostas e os subsídios fornecidos pelo Conselho Nacional de Turismo, bem como avaliar a sua execução; $</ p>$

II - coordenar a elaboração do Plano Nacional de Turismo;

III - conceber instrumentos e propor normas para a implementação da Política Nacional de Turismo;

IV - subsidiar a formulação, a elaboração e avaliar os planos, programas e ações ministeriais necessários à consecução da Política Nacional de Turismo;

$\mathrm{V}$ - conceber as diretrizes para a formulação de estudos, pesquisas, análises e levantamentos de dados destinados à formulação, implementação e avaliação da Política Nacional de Turismo;

$\mathrm{VI}$ - desempenhar as funções de Secretaria-Executiva do Conselho Nacional de Turismo;

VII - orientar o levantamento e a estruturação dos indicadores relativos ao turismo, com a finalidade de acompanhar a dinâmica do mercado turístico nacional e internacional e subsidiar a avaliação da implementação da Política Nacional de Turismo;

VIII - atuar, participar e articular-se com organismos e instâncias nacionais e internacionais, visando ao desenvolvimento do turismo nacional;

IX - promover a cooperação e articulação com os órgãos da Administração Pública federal, estadual, do Distrito Federal e municipal em projetos de suas iniciativas que possam contribuir para o fortalecimento e desenvolvimento do turismo nacional; e

$\mathrm{X}$ - articular com os demais órgãos governamentais e entidades da administração pública em seus programas, projetos e ações que tenham interface com a Política Nacional de Turismo.

Art. $8^{\circ}$ Ao Departamento de Planejamento e Avaliação do Turismo compete:

I - planejar, coordenar e avaliar a Política Nacional de Turismo;

II - coordenar a elaboração e avaliação do Plano Nacional de Turismo;< $/ p>$

III - elaborar os instrumentos e normas destinados à implementação da Política Nacional de Turismo;

IV - realizar estudos, pesquisas, análises e levantamentos de dados e indicadores necessários à formulação, implementação e avaliação da Política Nacional de Turismo;

V - acompanhar a dinâmica do mercado turístico nacional e internacional com vistas à subsidiar a formulação e avaliação da Política Nacional de Turismo; e

VI - secretariar o Conselho Nacional de Turismo. 
Art. $9^{\circ}$ Ao Departamento de Relações Institucionais compete:

I - coordenar e exercer a articulação com os demais órgãos e entidades da administração pública e não governamentais em seus programas, projetos e ações que tenham interface com a Política Nacional de Turismo;

II - coordenar e exercer a cooperação e articulação com os órgãos da Administração Pública federal, estadual, do Distrito Federal e municipal em projetos de suas iniciativas que possam contribuir para o fortalecimento $e$ desenvolvimento do turismo nacional;

III - apoiar o planejamento de programas e projetos no âmbito da Administração dos Estados, Distrito Federal, de Municípios e de micro-regiões que contribuam para o fortalecimento e desenvolvimento sustentável local pelo incremento da atividade turística; e

IV - promover a integração dos programas e ações do Ministério com sua entidade vinculada.

Art. 10. Ao Departamento de Relações Internacionais do Turismo compete:

I - apoiar, planejar, coordenar e acompanhar a atuação e participação do Ministério do Turismo em fóruns e organismos internacionais de interesse do turismo nacional;

II - apoiar, planejar, coordenar e acompanhar a celebração de acordos e instrumentos de cooperação técnica internacional;

III - apoiar, planejar, coordenar e acompanhar a atuação do Ministério nas negociações de acordos comerciais bilaterais, regionais e multilaterais, com fins do fortalecimento do turismo nacional no cenário internacional; e

IV - apoiar, planejar, coordenar e acompanhar a articulação com os demais órgãos e instituições governamentais com atuação no cenário internacional. compete:

Art. 11. À Secretaria de Programas de Desenvolvimento do Turismo

I - subsidiar a formulação dos planos, programas e ações destinados ao desenvolvimento e fortalecimento do turismo nacional, necessários à consecução da Política Nacional de Turismo;

II - subsidiar a formulação e acompanhar os programas de desenvolvimento regional de turismo e a promoção do apoio técnico, institucional e financeiro necessário ao fortalecimento da execução e participação dos Estados, do Distrito Federal e dos Municípios, nesses programas;

III - subsidiar o desenvolvimento de planos, projetos e ações para a captação e estímulo aos investimentos privados nacionais e internacionais, em conformidade com as diretrizes da Política Nacional de Turismo;

IV - promover a cooperação e a articulação dos instrumentos da Administração Pública para financiamento, apoio e promoção da atividade turística; e

V-coordenar, supervisionar e avaliar os planos e programas de incentivo ao turismo. 
Art. 12. Ao Departamento de Programas Regionais de Desenvolvimento do Turismo compete:

I-subsidiar a formulação, coordenar, apoiar e acompanhar os programas regionais de desenvolvimento do turismo, que objetivem beneficiar as populações locais e o incremento da renda gerada pelo turismo nacional e internacional;

II-subsidiar a formulação, coordenar, apoiar e acompanhar a promoção do apoio técnico, institucional e financeiro necessário ao fortalecimento da execução e participação dos Estados, do Distrito Federal e dos Municípios, nestes programas;

III - subsidiar a formulação, coordenar, apoiar e acompanhar a estrutura institucional e financeira adequada para a execução dos programas regionais de desenvolvimento do turismo;

IV - subsidiar a formulação, coordenar, apoiar e acompanhar o aporte de recursos de responsabilidade do Ministério, em conformidade com as diretrizes e a matriz de financiamento de cada programa; e

V-coordenar e acompanhar a integração das ações de sua competência com a EMBRATUR.

Art. 13. Ao Departamento de Financiamento e Promoção de Investimentos no Turismo compete:

I - subsidiar a formulação, coordenar, apoiar e acompanhar as ações de estímulo e fomento à mobilização da iniciativa privada, nacional e internacional, para a sua participação ativa na implementação da Política Nacional de Turismo;

II - subsidiar a formulação, coordenar, apoiar e acompanhar o desenvolvimento de planos, projetos e eventos que objetivem a captação e estímulo aos investimentos nacionais e internacionais, em ações integradas com as diretrizes e nas regiões beneficiadas pelos programas de desenvolvimento do turismo;

III-subsidiar a formulação, coordenar, apoiar e acompanhar o desenvolvimento, a manutenção e a promoção de projetos e de oportunidades de investimentos;

IV - subsidiar a formulação, coordenar, apoiar e acompanhar o desenvolvimento, junto a instituições financeiras de linhas de crédito e outros instrumentos financeiros, voltados para o financiamento ao turista e às empresas da cadeia produtiva do turismo; e

V-coordenar e acompanhar a integração das ações de sua competência com a EMBRATUR.

Art. 14. Ao Departamento de Capacitação e da Produção Associada ao Turismo compete:

I - formatar e implementar os planos, programas e ações voltados ao desenvolvimento da produção artesanal e demais produtos associados ao turismo; $</ p>$

II - coordenar as ações voltadas para a promoção e comercialização da produção artesanal e demais produtos associados ao turismo; 
III - formatar e implementar os programas e ações voltadas ao desenvolvimento da capacitação profissional; e

IV - coordenar as ações voltadas à capacitação profissional e à melhoria da qualidade dos serviços prestados ao turista.

Seção III

Do Órgão Colegiado

Art. 15. O Conselho Nacional de Turismo, criado pelo art. 27 da Medida Provisória $\mathrm{n}^{\circ}$ 2.216-37, de 31 de agosto de 2001, cabe exercer as competências estabelecidas em regulamento específico.

\section{CAPÍTULO IV}

DAS ATRIBUIÇÕES DOS DIRIGENTES

Seção I

Do Secretário-Executivo

Art. 16. Ao Secretário-Executivo incumbe:

I- coordenar, consolidar e submeter ao Ministro de Estado o planejamento da ação global do Ministério, em consonância com as diretrizes do Governo federal; Ministério;

II - supervisionar e avaliar a execução dos projetos e atividades do

III - supervisionar e coordenar a articulação dos órgãos do Ministério com os órgãos centrais dos sistemas afetos à área de competência da SecretariaExecutiva;

IV - supervisionar e coordenar as Secretarias integrantes da estrutura do Ministério; e

Estado.

$\mathrm{VI}$ - exercer outras atribuições que Ihe forem cometidas pelo Ministro de

Seção II

Dos Secretários e demais Dirigentes

Art. 17. Aos Secretários, ao Chefe de Gabinete do Ministro, ao Consultor Jurídico, ao Subsecretário, aos Diretores e aos demais dirigentes incumbe planejar, dirigir, coordenar e orientar a execução das atividades dos respectivos órgãos ou unidades e exercer outras atribuições que lhes forem cometidas em suas áreas de competência.

\section{CAPÍTULO V}

DAS DISPOSIÇÕES GERAIS 
Art. 18. O regimento interno definirá o detalhamento dos órgãos integrantes da Estrutura Regimental do Ministério do Turismo, as competências das respectivas unidades e as atribuições de seus dirigentes. 